\title{
geosciences
}

ISSN 2076-3263

www.mdpi.com/journal/geosciences

Article

\section{Modification of the Continental Crust by Subduction Zone Magmatism and Vice-Versa: Across-Strike Geochemical Variations of Silicic Lavas from Individual Eruptive Centers in the Andean Central Volcanic Zone}

\author{
Gary S. Michelfelder ${ }^{1, *},{ }^{\dagger}$, Todd C. Feeley ${ }^{1}$, Alicia D. Wilder ${ }^{1}$ and Erik W. Klemetti ${ }^{2}$ \\ 1 Department of Earth Sciences, Montana State University, Bozeman, MT 59717, USA; \\ E-Mails: tfeeley@montana.edu (T.C.F.); alicia.wilder@msu.montana.edu (A.D.W.) \\ 2 Department of Geosciences, Denison University, Granville, OH 43023, USA; \\ E-Mail:klemettie@denison.edu
}

$\dagger$ Present Address: Department of Geography, Geology and Planning, Missouri State University, Springfield, MO 65897, USA.

* Author to whom correspondence should be addressed; E-Mail: gary.michelfelder@msu.montana.edu; Tel.: +1-406-994-6916; Fax: +1-406-994-6923.

Received: 2 May 2013; in revised form: 8 November 2013 / Accepted: 14 November 2013 / Published: 27 November 2013

\begin{abstract}
To better understand the origin of across-strike $\mathrm{K}_{2} \mathrm{O}$ enrichments in silicic volcanic rocks from the Andean Central Volcanic Zone, we compare geochemical data for Quaternary volcanic rocks erupted from three well-characterized composite volcanoes situated along a southeast striking transect between $21^{\circ}$ and $22^{\circ} \mathrm{S}$ latitude (Aucanquilcha, Ollagüe, and Uturuncu). At a given $\mathrm{SiO}_{2}$ content, lavas erupted with increasing distance from the arc front display systematically higher $\mathrm{K}_{2} \mathrm{O}, \mathrm{Rb}$, Th, Y, REE and HFSE contents; $\mathrm{Rb} / \mathrm{Sr}$ ratios; and $\mathrm{Sr}$ isotopic ratios. In contrast, the lavas display systematically lower $\mathrm{Al}_{2} \mathrm{O}_{3}, \mathrm{Na}_{2} \mathrm{O}, \mathrm{Sr}$, and $\mathrm{Ba}$ contents; $\mathrm{Ba} / \mathrm{La}, \mathrm{Ba} / \mathrm{Zr}, \mathrm{K} / \mathrm{Rb}$, and $\mathrm{Sr} / \mathrm{Y}$ ratios; $\mathrm{Nd}$ isotopic ratios; and more negative Eu anomalies toward the east. We suggest that silicic magmas along the arc front reflect melting of relatively young, mafic composition amphibolitic source rocks and that the mid- to deep-crust becomes increasingly older with a more felsic bulk composition in which residual mineralogies are progressively more feldspar-rich toward the east. Collectively, these data suggest the continental crust becomes strongly hybridized beneath frontal arc localities due to protracted intrusion of primary, mantle-derived basaltic
\end{abstract}


magmas with a diminishing effect behind the arc front because of smaller degrees of mantle partial melting and primary melt generation.

Keywords: across-strike geochemical variation; Central Volcanic Zone; Aucanquilcha; Ollagüe; Uturuncu

\section{Introduction}

Continental arc volcanoes represent a dramatic surface expression of one of the most significant and fundamental phenomena in global tectonics: subduction of an oceanic plate beneath a more buoyant continental plate. The subduction of an oceanic plate results in recycling of crustal material into the convecting mantle, partial melting, and primary basalt production. Moreover, during passage through thick continental crust, subduction zone magmas may substantially differentiate and melt crustal rocks giving rise to the great diversity of igneous lithologies characteristic of Earth. These are important processes that must be understood in detail in order to interpret the long-term evolution of subduction zone systems on Earth and the generation of continental crust.

Although exceptions exist, one of the most remarkable features of arc magmatism is the systematic increase in the contents of $\mathrm{K}_{2} \mathrm{O}$ and other incompatible trace elements in volcanic rocks erupted with increasing vertical distance to the Benioff zone [1-4]. Understanding the significance of these trends has long been a major objective of petrologists due to the broader implications for regional tectonic complexities and magma generation processes, in addition to advancing understanding of arc magmatism. Despite decades of intense study, the origins of across-strike geochemical variations in intra-oceanic arcs are still vigorously debated; they are considerably less understood in continental arcs. As emphasized by Dickinson [5], interpreting the origin of these variations is inherently difficult in continental arcs due to the scarcity of primary, or near-primary basalts and the complicating effects of crustal contamination. For these reasons most of the better studied examples are from arcs underlain by relatively thin and, or, young continental crust where the potential for contamination is reduced [3,6-19].

Much has been learned about arc magmatism since publication of Gill's [2] classic book on the subject, although much remains to be learned. Because of its exceptionally thick continental crust and numerous well preserved volcanic centers, the Central Volcanic Zone (CVZ) presents a unique opportunity to advance understanding of fundamental problems such as how silicic magmas are generated in continental arcs, how the continental crust may modify the compositions of primary arc magmas in space and time [7,17,20-22], and how arc magmas may, in turn, spatially and temporally modify the composition of the crust through which these magmas ascend and differentiate [23-27].

In this study we examine and interpret across-arc geochemical trends of $<1 \mathrm{Ma}$ silicic volcanic rocks (andesites to dacites) erupted from three composite volcanoes in the Andean Central Volcanic Zone (CVZ) of northern Chile and southwest Bolivia $\left(21^{\circ}-22^{\circ} \mathrm{S}\right.$ latitude; Figure 1) and use this information to shed light on how the continental crust may influence across-arc trends in magma chemistry. Associated with active eastward subduction of the oceanic Nazca plate beneath the continental South American plate, the CVZ represents an end member in subduction zone systems on 
Earth because the continental crust is thicker $(70-80 \mathrm{~km})$ than at any other convergent margin setting [28-35]. The centers examined in this study were selected because of the young and limited range in ages (<1 Ma), quality and availability of comprehensive data sets (including isotopic data), and similarity in eruptive histories (i.e., effusive eruptions from andesitic to dacitic composite cones). In addition, we selected centers that span the range of volcanic activity in the arc, but show a small $\mathrm{N}-\mathrm{S}$ coverage area, in order to minimize potential along-arc variations in magma sources and processes. Other volcanic centers are present within the study area that fit some of the above mentioned criteria, but no other centers were identified that fit all three of the controls. These restrictions allow for a more focused examination relative to larger regional studies (i.e., [22,36,37]). Previous regional-scale studies of magmatism in the southern Altiplano region documented eastward increases in $\mathrm{K}_{2} \mathrm{O}$ and related incompatible trace elements virtually identical to across-strike geochemical trends observed at many oceanic island arcs and continental arcs constructed on thin crust [38-45].

Figure 1. Map showing location of Andean Central Volcanic Zone (CVZ). Shaded area shows the region where crustal thickness exceeds $60 \mathrm{~km}[30,32,33,46]$; stippled region illustrates distribution of Quaternary volcanic rocks. Modified from Feeley and Hacker [47]. Red box highlights the region illustrated in Figure 2.

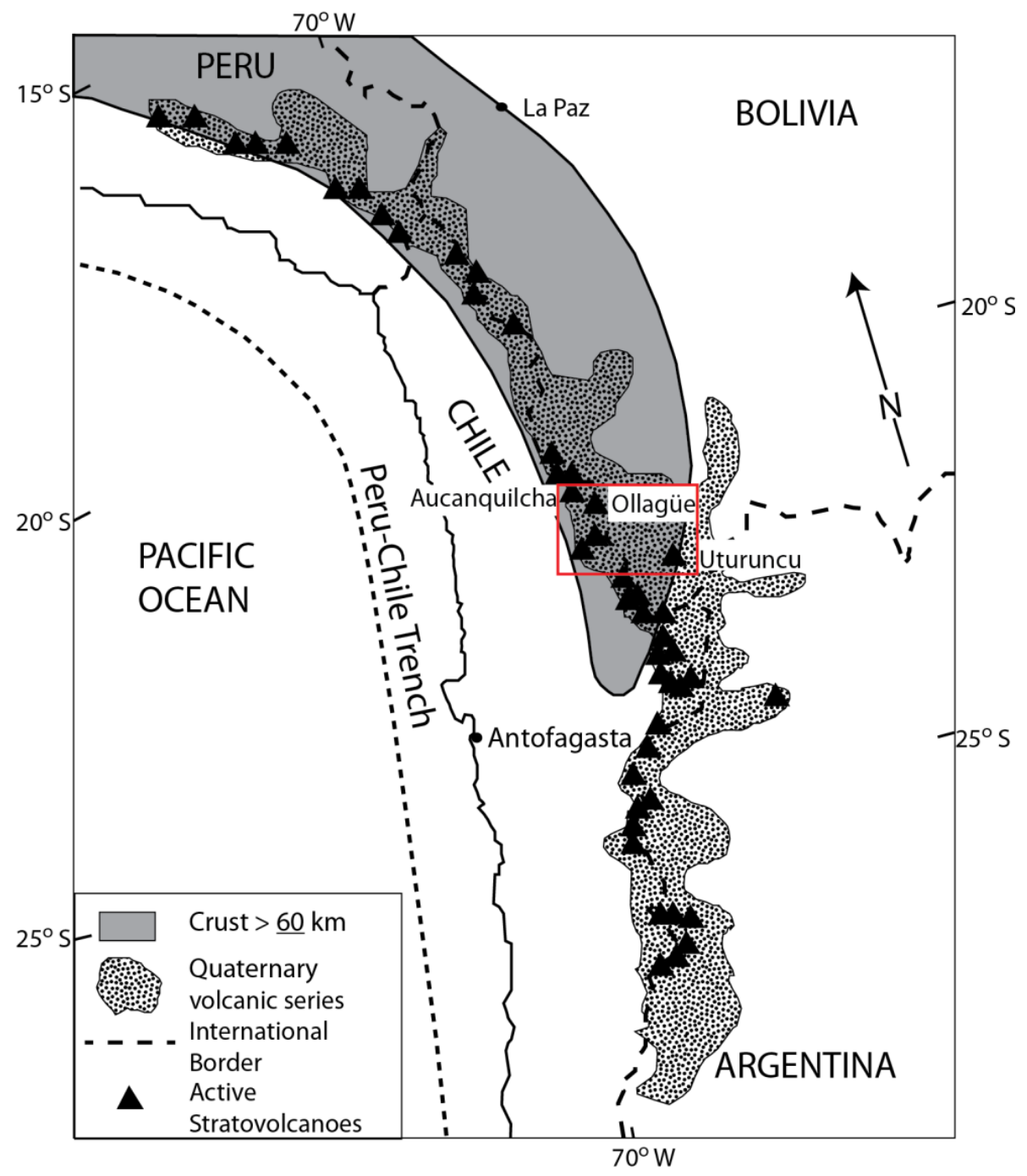


Figure 2. Simplified geologic map of the southern Altiplano and surrounding region (modified from Sparks et al. [48]). Only potentially active volcanoes as defined by de Silva and Francis [49] and volcanoes on the southern Altiplano are illustrated. Labeled volcanic centers are those considered in this study due to the quality of data sets available for other volcanic centers within the study area. The thick dashed line trending NW-SE across the Bolivian-Argentine border is interpreted from Allmendinger et al. [28] and is considered to be the general boundary between the Bolivian Altiplano (north) and the Argentine Puna (south).

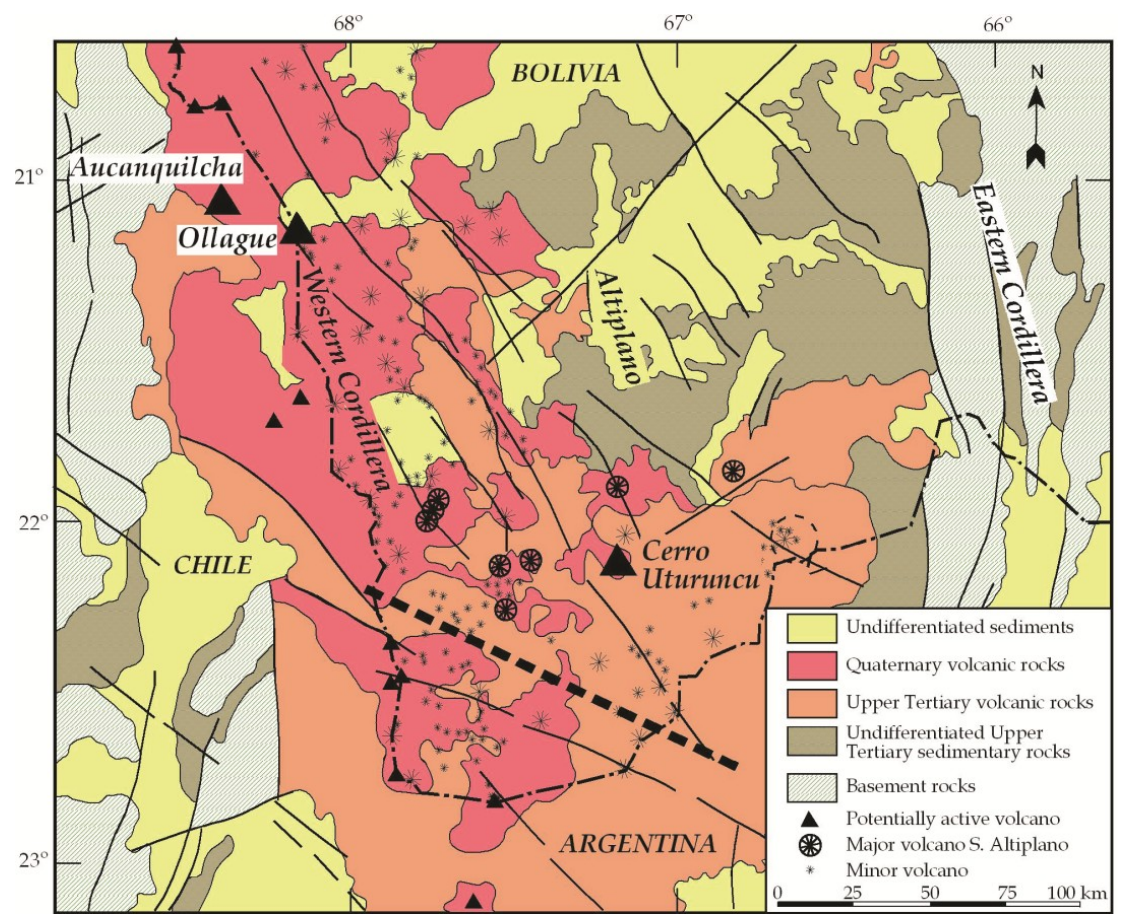

\section{Background: Tectonic and Geologic Setting}

\subsection{Regional Setting}

The Andes are generally considered the classic example of a modern Cordilleran type orogen formed by long-term subduction of oceanic lithosphere beneath continental lithosphere. The central Andes, in particular, represent the type locality for this process owing to the great width of the orogen and immense crustal thicknesses (up to $70-80 \mathrm{~km}$; [29]) and high elevations ( 4-6 km; [50]) that occur over vast areas (Figure 1). The region composes one of the youngest and largest active silicic volcanic provinces on Earth with recent caldera formation. It contains over 20 calderas and numerous ignimbrites (large ash flow sheets) less than $10 \mathrm{Ma}$ as well as an estimated 50 active or recently active composite volcanoes [51-53].

The modern central Andes at $21^{\circ}-22^{\circ} \mathrm{S}$ latitude are divided into three north- to north-west striking geological and upper crustal provinces. From west to east these are: (1) the Western Cordillera: an active volcanic arc bounded on the west by a westward dipping monocline; (2) the Altiplano: a broad, elevated plateau $(>3800 \mathrm{~m})$ where undeformed late-Miocene and younger volcanic rocks overlie variably folded and faulted mid-Miocene and older sedimentary and volcanic rocks; and (3) the Eastern Cordillera: a major east-verging thrust complex involving Paleozoic to Mesozoic sedimentary 
and metamorphic rocks. The largest volumes of intermediate composition lavas at $21^{\circ}-22^{\circ} \mathrm{S}$ latitude erupted from composite volcanoes that form the peaks of the Western Cordillera. Baker and Francis [53] estimated that the Western Cordillera contains $\sim 3000 \mathrm{~km}^{3}$ of these lavas between $21^{\circ}$ and $22^{\circ} \mathrm{S}$ latitude. Lavas associated with composite volcanoes extend for $\sim 200 \mathrm{~km}$ eastward onto the Altiplano, although volumes decrease sharply to $<800 \mathrm{~km}^{3}$ [53].

The youngest rocks in the southern Altiplano region of the CVZ were erupted following relatively recent changes in the subduction history of the CVZ. These changes are related to breakup of the Farallon plate into the Cocos and the Nazca plates, which increased the rate of subduction beneath the South American plate $[16,54-56]$. Between $15^{\circ}$ and $28^{\circ} \mathrm{S}$ latitude the present day subduction angle of $\sim 30^{\circ}$ allows for an expression of magmatism that is absent from $2^{\circ}$ to $15^{\circ} \mathrm{S}$ where the subduction angle is between $5^{\circ}$ and $10^{\circ}$ [57]. Uplift of the Altiplano and thickening of the CVZ crust are believed to be related, in part, to the recent steepening of the subducting slab [16,58,59]. In this study we focus on compositional variations of rocks on and behind the Quaternary arc-front that erupted after the last major episode of regional crustal thickening and shortening in the region.

\subsection{Individual Volcanic Centers}

Aucanquilcha is a long lived $(11 \mathrm{Ma})$ volcanic complex located on the volcanic front in northern Chile (Figures 1 and 2; [27]). The Aucanquilcha Volcanic Complex consists of 4 distinct volcanic groups: the Alconcha Group (11 to $8 \mathrm{Ma}$ ), the Gordo Group (6 to $4 \mathrm{Ma}$ ), the Polan Group ( $\sim 4$ to $2 \mathrm{Ma}$ ), and Volcán Aucanquilcha $(<1 \mathrm{Ma} ;[27,60])$. There are long hiatuses between the Aconcha and Gordo Groups and between the Polan Group and Volcán Aucanquilcha. This paper focuses exclusively on the eruptive products of Volcán Aucanquilcha.

Eruptive products from Volcán Aucanquilcha range in age from 1.04 to $0.24 \mathrm{Ma}$ [60]. Volcán Aucanquilcha experienced four stages of growth as defined by Klemetti and Grunder [60]: the Azufrera, Rodado, Cumbre Negra and Angulo stages. These stages are not uniquely distinguished on the basis of location or time, and all are dominantly dacitic in composition. Eruptive units of the Azufrera stage (1.04 to $0.94 \mathrm{Ma}$ ) make up the main edifice of the volcano [60]. These units are mainly blocky two-amphibole (with the exception of the Rodado Stage) plus biotite dacitic lava flows [60,61]. Nearly all lavas contain undercooled basaltic andesitic to andesitic magmatic inclusions that compose $1 \%-10 \%$ of the total volume of the lavas $[27,60]$.

Volcán Ollagüe straddles the Bolivia-Chile border approximately $25 \mathrm{~km}$ to the east of the arc front (Figures 1 and 2; [41]). It is a composite volcano with no Holocene eruptions [62]. Feeley et al. [63] described four eruptive series (Vinta Loma, Chasca Orkho, La Celosa, and post-collapse) and a debris avalanche deposit resulting from sector collapse of the western flank of the volcano. These series were subsequently sub-divided into ten sequences by Wörner et al. [64], Clavero et al. [65], and Vezzoli et al. [66].

Ollagüe was primarily active between $1.2 \mathrm{Ma}$ and $130 \mathrm{ka}$. Currently the volcano shows signs of activity through active degassing of fumaroles that vent from a young dacitic dome on the upper western flank $[63,65]$. Compositions of eruptive products range from basaltic andesitic to dacitic lava flows and domes covering an estimated area of $\sim 230 \mathrm{~km}^{2}$ with a volume of $\sim 85 \mathrm{~km}^{3}$ [63]. In addition, basaltic andesitic to andesitic magmatic inclusions are present in varying proportions in nearly all lava 
flows, although they are more abundant in younger units. The volcano is built upon 8 to $5 \mathrm{Ma}$ ignimbrite deposits [47].

Cerro Uturuncu is an andesitic to mainly dacitic composite volcano located in the southern Altiplano region of the CVZ in southwest Bolivia, approximately $120 \mathrm{~km}$ east of the arc front (Figures 1 and 2; [48]). The volcano was primarily active between 890 and $271 \mathrm{ka}$. Eruptive products define two series as described by Sparks et al. [48]. The first series is more extensive older material ranging from 890 to $549 \mathrm{ka}$. These flows and domes rest directly on approximately $5 \mathrm{Ma}$ ignimbrites [49]. The second series consists of younger flows covering about $10 \mathrm{~km}^{2}$, mostly located on the upper flanks of the edifice. These flows range from 427 to $271 \mathrm{ka}$ and are built upon the first series flows and domes [48]. Most flows and domes sampled by Sparks et al. [48] and in this study contain undercooled andesitic magmatic inclusions that compose no more than a few volume percent of the host rocks. In many older rocks magmatic inclusions are rarer [48]. This relationship is similar to that seen at Aucanquilcha [60] and Ollagüe [63] where magmatic inclusions are typically more abundant in younger lavas.

\section{Methods}

New whole rock analyses for Uturuncu rocks were performed at Washington State University, Pullman. Major and trace element analyses on 121 samples were performed by X-ray Fluorescence Spectrometry (XRF) on a ThermoARL Advant'XP+ automated sequential wavelength spectrometer (ThermoARL, Waltham, MA, USA). Methods and errors for the XRF analyses are described in Johnson et al. [67]. 65 distinct geochemical samples were further analyzed for trace elements, including the rare earth elements, by Inductively Coupled Plasma Mass Spectrometry (ICP-MS) on an Agilent Technologies 7700 ICP-MS (Agilent Technologies, Conesus, NY, USA). Methods and errors for trace element analyses are detailed in Jarvis [68].

Whole rock $\mathrm{Nd}$ and $\mathrm{Sr}$ isotopic analyses on 30 samples were acquired by Thermal Ionization Mass Spectrometry (TIMS) on a VG Sector 54 (VG, Santa Clara, CA, USA) and analyzed by five Faraday collectors in dynamic mode at New Mexico State University, Las Cruces. Calibration of ${ }^{87} \mathrm{Sr} /{ }^{86} \mathrm{Sr}$ ratios was calculated using the ${ }^{86} \mathrm{Sr} /{ }^{88} \mathrm{Sr}$ ratio analyzed at $3.0 \mathrm{~V}$ aiming intensity and normalized to $0.1194 \mathrm{using}$ NBS 987 Standard $(0.710298+0.000010)$ to monitor the precision of the analyses. Sr was isolated using Sr-Spec resin column chromatography by the method described in Ramos and Reid [69]. Nd was separated using REE resin column chromatography using the digested split of prepared sample for $\mathrm{Sr}$ chromatography. $\mathrm{Nd}$ isotopes were normalized to ${ }^{146} \mathrm{Nd} /{ }^{144} \mathrm{Nd}=0.7219$ and results for JNDi-1 were ${ }^{146} \mathrm{Nd} /{ }^{144} \mathrm{Nd}=0.512137 \pm 0.000009$ for five analyses. $\mathrm{Pb}$ isotopes were separated from the same digested samples used for $\mathrm{Sr}$ and $\mathrm{Nd}$ isotope ratios. $\mathrm{Pb}$ separations used $\sim 2 \mathrm{~mL}$ of anion exchange resin in a high-aspect ratio glass column with an eluent of $1 N \mathrm{HBr}$ and $7 N \mathrm{HNO}_{3}$. Purified samples were then dried and re-dissolved in $1 \mathrm{~mL}$ of $2 \% \mathrm{HNO}_{3}$ containing $0.01 \mathrm{ppm}$ Tl. Samples were analyzed on a ThermoFinnigan Neptune multi-collector ICP-MS (ThermoFinnigan, Waltham, MA, USA) equipped with nine Faraday collectors and an ion counter. The standard NBS $981\left({ }^{208} \mathrm{~Pb} /{ }^{204} \mathrm{~Pb} \approx 36.662 \pm 0.002\right.$, ${ }^{207} \mathrm{~Pb} /{ }^{204} \mathrm{~Pb} \approx 15.462 \pm 0.001,{ }^{206} \mathrm{~Pb} /{ }^{204} \mathrm{~Pb} \approx 16.928 \pm 0.001$ ) was used for accuracy corrections and to monitor precision of the analyses. The values measured for NBS 981 were within the error of published ratios for NBS 981 [70] and therefore corrections were not applied to unknown sample 
ratios. Given the young ages of all rocks examined in this study, no age corrections were performed for the radiogenic isotope data.

$\delta^{18} \mathrm{O}$ values were determined for 30 Uturuncu samples by the laser fluorination method described by Takeuchi and Larsen [71] at Washington State University, Pullman. Quartz and plagioclase phenocryst separates were analyzed twice to insure reproducibility. The standard UWG-2 was measured with a difference of $0.2 \%$ from the published value of 5.89\% [71,72]. Data are illustrated in figures and presented in Table 1 in permil using standard delta notation relative to Vienna Standard Mean Ocean Water (VSMOW).

Table 1. Representative new whole rock samples from Cerro Uturuncu.

\begin{tabular}{|c|c|c|c|c|c|}
\hline Sample & DM10A & DM58A2 & GSM17 & GSM29 & GSM-50 \\
\hline $\mathrm{SiO}_{2}$ & 65.55 & 62.30 & 66.59 & 63.65 & 64.84 \\
\hline $\mathrm{TiO}_{2}$ & 1.08 & 1.13 & 1.00 & 0.99 & 1.08 \\
\hline $\mathrm{Al}_{2} \mathrm{O}_{3}$ & 16.16 & 17.19 & 15.84 & 16.11 & 16.25 \\
\hline $\mathrm{FeO}^{*}$ & 4.81 & 5.73 & 4.47 & 5.24 & 4.93 \\
\hline $\mathrm{MnO}$ & 0.07 & 0.09 & 0.06 & 0.07 & 0.07 \\
\hline $\mathrm{MgO}$ & 1.87 & 2.60 & 1.61 & 3.07 & 2.11 \\
\hline $\mathrm{CaO}$ & 4.14 & 4.95 & 3.64 & 4.69 & 4.11 \\
\hline $\mathrm{Na}_{2} \mathrm{O}$ & 2.37 & 2.21 & 2.41 & 2.23 & 2.29 \\
\hline $\mathrm{K}_{2} \mathrm{O}$ & 3.70 & 3.49 & 4.11 & 3.67 & 4.01 \\
\hline $\mathrm{P}_{2} \mathrm{O}_{5}$ & 0.25 & 0.30 & 0.28 & 0.28 & 0.32 \\
\hline LOI (\%) & 0.99 & 0.43 & 0.53 & 0.51 & 0.95 \\
\hline Sum & 100.00 & 100.00 & 100.00 & 100.00 & 100.00 \\
\hline $\mathrm{La}$ & 53 & 59 & 69 & 61 & 70 \\
\hline $\mathrm{Ce}$ & 109 & 118 & 140 & 120 & 141 \\
\hline $\operatorname{Pr}$ & 13 & 14 & 17 & 15 & 17 \\
\hline $\mathrm{Nd}$ & 50 & 53 & 61 & 54 & 62 \\
\hline $\mathrm{Sm}$ & 10 & 10 & 11 & 10 & 11 \\
\hline $\mathrm{Eu}$ & 1.80 & 1.98 & 1.89 & 1.90 & 1.97 \\
\hline $\mathrm{Gd}$ & 7.68 & 8.23 & 8.10 & 7.79 & 8.36 \\
\hline $\mathrm{Tb}$ & 1.11 & 1.25 & 1.11 & 1.10 & 1.18 \\
\hline Dy & 5.89 & 6.96 & 5.65 & 5.74 & 6.07 \\
\hline Но & 1.03 & 1.31 & 0.93 & 1.03 & 1.04 \\
\hline Er & 2.44 & 3.29 & 2.18 & 2.63 & 2.40 \\
\hline $\mathrm{Tm}$ & 0.33 & 0.45 & 0.29 & 0.37 & 0.31 \\
\hline $\mathrm{Yb}$ & 1.90 & 2.72 & 1.64 & 2.25 & 1.76 \\
\hline $\mathrm{Lu}$ & 0.27 & 0.40 & 0.24 & 0.33 & 0.25 \\
\hline $\mathrm{Ba}$ & 686 & 776 & 850 & 814 & 866 \\
\hline Th & 19 & 19 & 25 & 20 & 25 \\
\hline $\mathrm{Nb}$ & 18 & 21 & 19 & 19 & 22 \\
\hline $\mathrm{Y}$ & 27 & 33 & 25 & 27 & 27 \\
\hline Hf & 6.6 & 6.4 & 7.3 & 6.4 & 7.3 \\
\hline $\mathrm{Ta}$ & 1.4 & 1.5 & 1.4 & 1.3 & 1.5 \\
\hline $\mathrm{Rb}$ & 167 & 146 & 193 & 161 & 184 \\
\hline $\mathrm{Sr}$ & 305 & 474 & 338 & 391 & 388 \\
\hline $\mathrm{Zr}$ & 250 & 241 & 277 & 230 & 276 \\
\hline
\end{tabular}

Note: Total Fe reported as FeO*. 


\section{Results}

\subsection{Summary of Petrology and Petrogenetic Processes at $21^{\circ}-22^{\circ} S$ Latitude}

Rocks from all three centers are porphyritic with $30 \%$ to $60 \%$ by volume phenocrysts (average $\sim 40 \%$ ). Plagioclase is the most abundant phenocryst phase in all samples, accounting for $50 \%$ to $75 \%$ of the mineral assemblage in many of the samples. Other phenocryst phases are present in variable amounts and include orthopyroxene, clinopyroxene, amphibole, biotite, quartz, magnetite, and ilmenite. In general, phenocryst assemblages are similar for rocks from the three centers, except that amphibole and clinopyroxene are typically more abundant in young rocks from Aucanquilcha, whereas biotite is progressively more abundant in young rocks from Ollagüe and Uturuncu. The latter probably reflects the higher $\mathrm{K}_{2} \mathrm{O}$ contents of Ollagüe and Uturuncu rocks relative to rocks from Aucanquilcha.

Petrographic similarities such as those described above and the presence of undercooled magmatic inclusions that are slightly more mafic than the host lavas, suggest that Uturuncu magmas experienced similar petrogenetic processes to magmas erupted at Ollagüe and Aucanquilcha. Specifically, recent geochemical modeling of Uturuncu rocks suggests that the magmas were produced by complex processes involving magma mixing and mingling with more mafic magmas following assimilation of crustal rocks coupled with fractional crystallization (AFC) in multiple reservoirs within both the mid-deep and shallow crust $[73,74]$. This is consistent with the work of Sparks et al. [48] who, on the basis of geochemical and petrologic data, concluded that dacitic magmas at Uturuncu formed by fractional crystallization of andesite forming norite cumulates and involving partial melting and assimilation of the continental crust. Furthermore, phenocryst compositions and zoning patterns indicate that more detailed compositional variations of the dacites reflect magma mixing with silicic andesite at shallow crustal levels. The latter conclusion is supported by geophysical evidence that indicates magma accumulation and seismicity clusters at sea level beneath Uturuncu (6 km depth; [75-77]).

The petrologic model for Uturuncu rocks $[48,73,74]$ is nearly identical to those proposed by Feeley and Davidson [25] and Feeley and Hacker [47] for production of magmas at Ollagüe and Klemetti and Grunder [60] and Walker et al. [78] for production of magmas at Aucanquilcha. These authors argue that magma mixing with a component of mid-deep crustal AFC were responsible for producing the rock compositions observed at these two centers. Therefore, mid-deep crustal AFC is considered the dominant process in producing the dacitic rocks erupted at the three centers followed by mixing and mingling with more mafic melts and undercooled inclusions, respectively, in shallow reservoirs to produce rocks lower in $\mathrm{SiO}_{2}$ contents. The most silicic rocks erupted the three centers are thus all considered to contain a significant crustal component derived from melting and assimilation of mid-deep crustal local basement lithologies.

\subsection{Across-Arc Geochemical Variations}

In this section we describe across-arc geochemical and isotopic variations of silicic volcanic rocks (i.e., $>60 \mathrm{wt} \% \mathrm{SiO}_{2}$ ) erupted from the three centers. We focus on silicic rocks because more mafic rocks are generally rare or non-existent at the three centers and the silicic rocks better record the compositions of crustal rocks through which the magmas ascended and interacted. Data for magmas erupted at Ollagüe and Aucanquilcha are in Feeley and Davidson [25], Feeley and Hacker [47], Feeley and Sharp [26], 
Mattoli et al. [79], Grunder et al. [27], Klemetti and Grunder [60], and Vezzoli et al. [66]. New whole rock and isotopic data are illustrated in this paper for Uturuncu rocks with representative analyses presented in Tables 1-3. A complete dataset for new analyses is available in the supplementary information. Additional major and trace element data for Uturuncu rocks are in Sparks et al. [48].

Table 2. Representative new whole rock trace element ratios from Cerro Uturuncu.

\begin{tabular}{|c|c|c|c|c|c|}
\hline Sample & DM10A & DM58A2 & GSM17 & GSM29 & GSM-50 \\
\hline $\mathrm{K}_{2} \mathrm{O}+\mathrm{Na}_{2} \mathrm{O}$ & 5.99 & 5.68 & 6.46 & 5.87 & 6.20 \\
\hline $\mathrm{Rb} / \mathrm{Sr}$ & 0.55 & 0.31 & 0.57 & 0.41 & 0.47 \\
\hline $\mathrm{Sr} / \mathrm{Y}$ & 11.48 & 14.25 & 13.59 & 14.48 & 14.54 \\
\hline $\mathrm{Ce} / \mathrm{Y}$ & 4.09 & 3.56 & 5.63 & 4.43 & 5.29 \\
\hline $\mathrm{Ce} / \mathrm{Yb}$ & 57.24 & 43.43 & 85.38 & 53.23 & 80.06 \\
\hline $\mathrm{Ba} / \mathrm{La}$ & 12.91 & 13.27 & 12.34 & 13.34 & 12.37 \\
\hline $\mathrm{Ba} / \mathrm{Zr}$ & 2.75 & 3.22 & 3.07 & 3.53 & 3.13 \\
\hline $\mathrm{K} / \mathrm{Rb}$ & 184.42 & 199.17 & 176.59 & 189.74 & 180.83 \\
\hline $\mathrm{Nb} / \mathrm{Zr}$ & 0.07 & 0.09 & 0.07 & 0.08 & 0.08 \\
\hline Dy/Dy* & 0.81 & 0.73 & 0.80 & 0.68 & 0.81 \\
\hline $\mathrm{Dy} / \mathrm{Yb}_{\mathrm{N}}$ & 2.01 & 1.66 & 2.24 & 1.66 & 2.23 \\
\hline $\mathrm{La} / \mathrm{Yb}_{\mathrm{N}}$ & 18.87 & 14.47 & 28.36 & 18.29 & 26.75 \\
\hline Eu Anomaly & 0.57 & 0.58 & 0.56 & 0.58 & 0.63 \\
\hline
\end{tabular}

Table 3. Representative new whole rock $\mathrm{Sr}, \mathrm{Nd}, \mathrm{Pb}$ whole rock isotopic ratios and ${ }^{18} \mathrm{O} /{ }^{16} \mathrm{O}$ ratios from mineral separates from Cerro Uturuncu.

\begin{tabular}{cccccc}
\hline Sample & DM10A & DM58A2 & GSM17 & GSM29 & GSM-50 \\
\hline${ }^{87} \mathrm{Sr} /{ }^{86} \mathrm{Sr}$ & 0.71457 & 0.711294 & 0.71385 & 0.71141 & 0.71247 \\
${ }^{144} \mathrm{Nd} /{ }^{143} \mathrm{Nd}$ & 0.51215 & 0.512179 & 0.51214 & 0.51223 & 0.51216 \\
${ }^{208 / 204} \mathrm{~Pb}$ & 38.94 & 38.92 & 38.94 & 38.9 & 38.93 \\
${ }^{207 / 204} \mathrm{~Pb}$ & 15.65 & 15.65 & 15.65 & 15.65 & 15.64 \\
${ }^{206 / 204} \mathrm{~Pb}$ & 18.87 & 18.84 & 18.84 & 18.84 & 18.86 \\
$\delta^{18} \mathrm{O}-\mathrm{QTZ}$ & 7.26 & 8.95 & - & 7.60 & 7.98 \\
$\delta^{18} \mathrm{O}-\mathrm{PLG}$ & - & 9.32 & - & - & 8.75 \\
\hline
\end{tabular}

Notes: $\delta^{18} \mathrm{O}-\mathrm{QTZ}$ represents mineral separate analyses of quartz phenocrysts; $\delta^{18} \mathrm{O}-\mathrm{PLG}$ represents mineral separate analyses of plagioclase phenocrysts.

Volcanic rocks at Aucanquilcha, Ollagüe, and Uturuncu are high-K, calc-alkaline andesites/trachyandesites and dacites/trachytes, together with less abundant basaltic andesites (Figure 3). Total alkali concentrations of rocks from Aucanquilcha and Ollagüe with $61-68 \mathrm{wt} \% \mathrm{SiO}_{2}$ are restricted, ranging from 5.1 to $7.9 \mathrm{wt} \%$, such that they plot along the border of the andesite-dacite/trachyte-trachyandesite fields (Figure 3; [27,60]). Ollagüe also contains a few rocks that plot in the trachyte and trachyandesite fields, but these are rare (Figure 3; $[23,25]$ ). Silicic rocks at Uturuncu with $\mathrm{SiO}_{2}$ contents from 61 to $68 \mathrm{wt} \%$ have lower total alkali concentrations of 5.5-6.7 wt \% 
(as a result of low $\mathrm{Na}_{2} \mathrm{O}$ concentrations; see below); classifying them as andesitic to dacitic (Figure 3; [23,25,48]).

Figure 3. Total alkalis vs. $\mathrm{SiO}_{2}$ contents and classification of silicic rocks from Aucanquilcha, Ollagüe and Uturuncu [80].

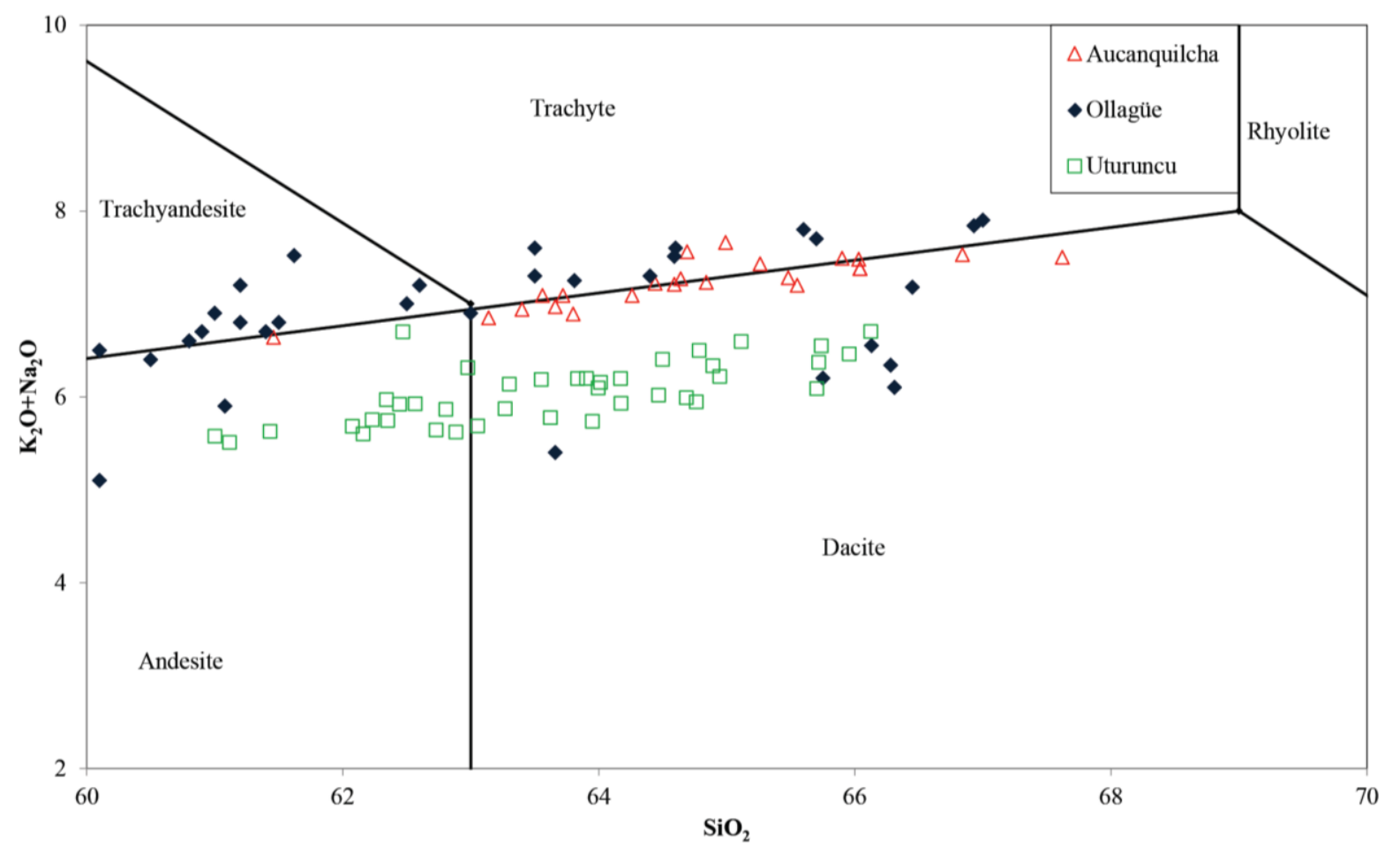

Systematic differences exist in the major and trace element compositions of rocks erupted with increasing distance from the arc front. At a given $\mathrm{SiO}_{2}$ content, $\mathrm{K}_{2} \mathrm{O}, \mathrm{FeO}, \mathrm{P}_{2} \mathrm{O}_{5}$, and $\mathrm{TiO}_{2}$ concentrations increase toward the east, particularly in the most silicic composition rocks, with the highest concentrations in rocks at Uturuncu (Figure 4). In contrast, contents of $\mathrm{CaO}, \mathrm{Al}_{2} \mathrm{O}_{3}$, and, particularly, $\mathrm{Na}_{2} \mathrm{O}$, decrease in concentration toward the east, with very low concentrations of the latter in Uturuncu rocks (Figure 4). In more detail, trends for $\mathrm{P}_{2} \mathrm{O}_{5}$ and $\mathrm{TiO}_{2}$ decrease with increasing $\mathrm{SiO}_{2}$ for lavas from Aucanquilcha and Ollagüe, whereas they increase with increasing $\mathrm{SiO}_{2}$ for lavas from Uturuncu.

At a given $\mathrm{SiO}_{2}$ content, all trace elements analyzed increase in rocks erupted progressively toward the east with the exception of $\mathrm{Sr}$ and $\mathrm{Ba}$ (Figure 5). In contrast, $\mathrm{Sr}$ (and to a lesser degree, Ba) concentrations decrease toward the east at a given $\mathrm{SiO}_{2}$ concentration (Figure 5). Chondrite-normalized REE patterns for rocks from Aucanquilcha and Ollagüe have similar slopes, although Ollagüe rocks have higher concentrations of REE compared to Aucanquilcha (Figure 6). In contrast, Uturuncu REE patterns have steeper slopes for middle to heavy REE compared to patterns for Ollagüe or Aucanquilcha rocks and higher concentrations (Figure 6). In these regards, with increasing $\mathrm{SiO}_{2}$ contents, $(\mathrm{La} / \mathrm{Yb})_{n}$ (when " $n$ " refers to chondrite normalized values) ratios increase for rocks from all centers and broadly overlap (although the most silicic rocks from Uturuncu have the highest ratios; Figure 7). In contrast, with increasing $\mathrm{SiO}_{2}$ concentrations, trends for $(\mathrm{Dy} / \mathrm{Yb})_{n}$ ratios are variable: they decrease in Aucanquilcha rocks, are roughly constant for the Ollagüe suite, and increase for Uturuncu rocks (Figure 7). Furthermore, negligible Eu anomalies are observed in REE patterns for rocks from 
Aucanquilcha (0.8-0.85) compared to small negative $\mathrm{Eu}$ anomalies in Ollagüe rocks (0.61-0.88; ratios close to one are considered small). Relatively large negative Eu anomalies (0.49-0.69) are observed for all Uturuncu rocks (Figures 6 and 7; Table 2).

Figure 4. Major element diagrams for volcanic rocks from Aucanquilcha, Ollagüe and Uturuncu rocks vs. $\mathrm{SiO}_{2}$.

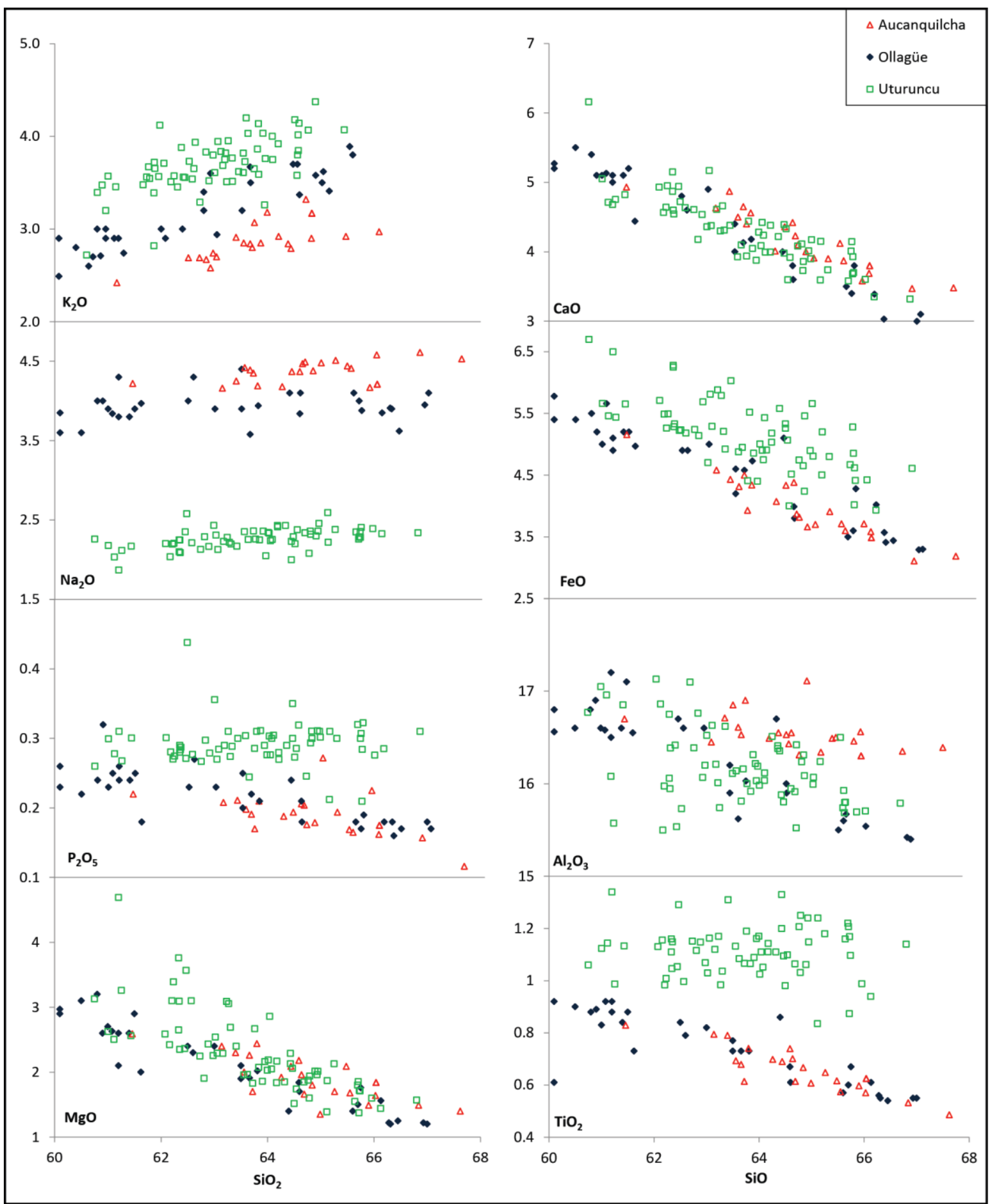


Figure 5. Plots of selected trace element compositions of Aucanquilcha, Ollagüe, and Uturuncu rocks vs. $\mathrm{SiO}_{2}$.

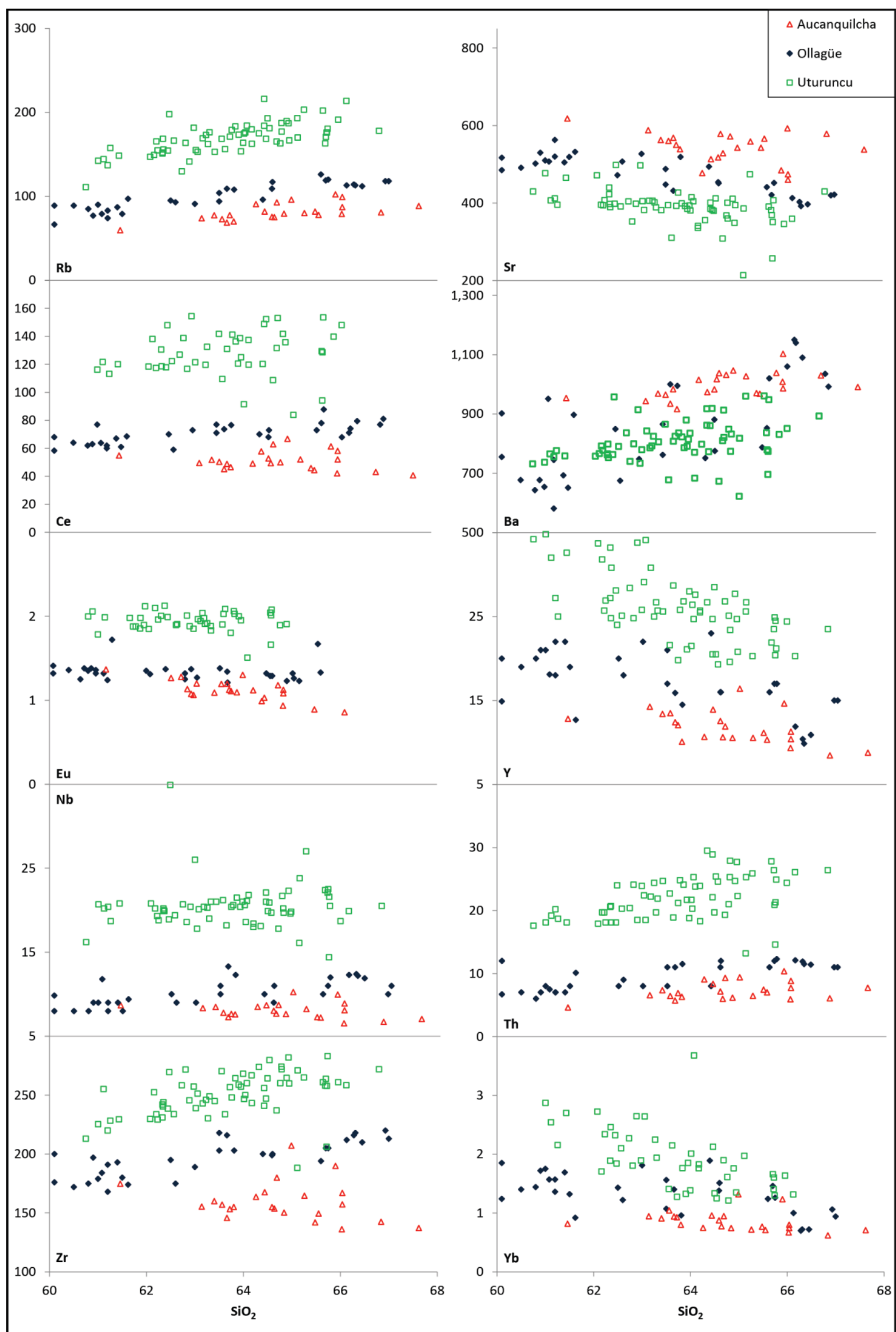


Figure 6. Rare earth element fields for whole rock samples from each volcanic center. Chondrite normalization values from Sun and Mcdonough [81].

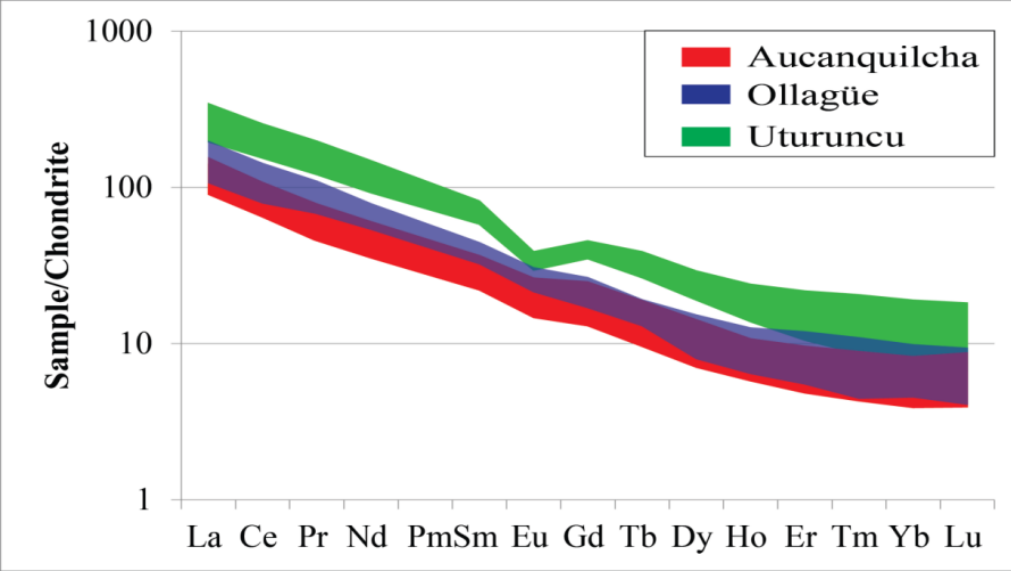

LILE to HFSE ratios (e.g., $\mathrm{Ba} / \mathrm{Zr}$ and $\mathrm{Rb} / \mathrm{Nb}$; the latter not illustrated), $\mathrm{K} / \mathrm{Rb}, \mathrm{Ba} / \mathrm{La}$, and $\mathrm{Eu} / \mathrm{Eu}^{*}$ decrease toward the east for a given $\mathrm{SiO}_{2}$ (Figure 7). $\mathrm{Nb} / \mathrm{Zr}$ and $\mathrm{Rb} / \mathrm{Sr}$ ratios increase toward the east with the highest ratios observed in Uturuncu rocks for a given $\mathrm{SiO}_{2}$ (Figure 7). Aucanquilcha rocks contain the highest $\mathrm{Sr} / \mathrm{Y}$ ratios for a given $\mathrm{Y}$ concentration (Figure 8). This ratio is lower in Ollagüe rocks and the lowest ratios are observed in Uturuncu rocks. Ratios of La/Ta show no correlation with distance from the arc front with the exception that there are no observed ratios for Aucanquilcha that fall below $\mathrm{La} / \mathrm{Ta}=40 . \mathrm{Ba} / \mathrm{Ta}$ ratios decrease towards the east. $\mathrm{Ba} / \mathrm{La}$ ratios for all observed rocks from Aucanquilcha and most rocks for Ollagüe are above the $\mathrm{Ba} / \mathrm{La}=20$ ratio indicative of their arc affiliation $[17,82]$.

Across-arc variations in $\mathrm{Sr}, \mathrm{Nd}$, and $\mathrm{O}$ isotope ratios generally parallel those observed for $\mathrm{K}_{2} \mathrm{O}$ and incompatible trace elements (with the exceptions of $\mathrm{Sr}$ and $\mathrm{Ba}$ ), particularly for the most silicic rocks erupted at any given center. In this regard, ${ }^{87} \mathrm{Sr} /{ }^{86} \mathrm{Sr}$ and ${ }^{18} \mathrm{O} /{ }^{16} \mathrm{O}$ ratios of Uturuncu rocks (Table 3) are highly elevated and become progressively lower in rocks erupted towards the arc front, whereas ${ }^{143} \mathrm{Nd} /{ }^{144} \mathrm{Nd}$ ratios increase (Figure 9). In detail, with increasing $\mathrm{SiO}_{2}$ contents, $\mathrm{Sr}$ and $\mathrm{Nd}$ isotopic ratios of rocks from Aucanquilcha decrease and increase, respectively, show small variations for rocks from Ollagüe, and increase and decrease, respectively, for rocks from Uturuncu.

On a plot of ${ }^{143} \mathrm{Nd} /{ }^{144} \mathrm{Nd} v s .{ }^{87} \mathrm{Sr} /{ }^{86} \mathrm{Sr}$, rocks from all three centers form a slightly scattered curvilinear array, becoming isotopically more "crustal-like" (i.e., plotting lower and further to the right from Bulk Earth $\left(\mathrm{BE} ;{ }^{143} \mathrm{Nd} /{ }^{144} \mathrm{Nd}=0.51263 ;{ }^{87} \mathrm{Sr} /{ }^{86} \mathrm{Sr}=0.7052 ;\right.$ [83])) with increasing distance from the arc front (Figure 10). This is a long observed trend in the CVZ as outlined by Kay et al. [17] and references within. Furthermore, on Figure 10, there is a distinct gap between magmas erupted at Uturuncu versus those erupted on or just to the east of the arc front. In a similar manner, $\delta^{18} \mathrm{O}$ values for the rocks as a group are elevated relative to generally accepted mantle values [24,84-86], thus requiring the incorporation of a significant crustal component during the petrogenesis of all studied suites. $\delta^{18} \mathrm{O}$ values of mineral separates are extremely variable for Uturuncu rocks $\left(\delta^{18} \mathrm{O}=7.3 \%{ }_{0}-9.6 \%\right.$ ) compared to Ollagüe $\left(\delta^{18} \mathrm{O}=7.3 \%{ }_{0}-8.3 \%\right.$ ) $)$ and Aucanquilcha rocks $\left(\delta^{18} \mathrm{O}=7 \%_{0}-7.3 \%\right.$ ) , in part reflecting that values for both plagioclase and quartz are illustrated for Uturuncu rocks. Nevertheless, Aucanquilcha rocks contain the lowest $\delta^{18} \mathrm{O}$ values and, while values for Uturuncu and Ollagüe overlap, ${ }^{18} \mathrm{O} /{ }^{17} \mathrm{O}$ ratios become on-average more crustal-like toward the east (Figure 9). 
Figure 7. Plots of selected trace element abundance ratios for Aucanquilcha, Ollagüe, and Uturuncu rocks $v s$. $\mathrm{SiO}_{2}$. Lines through data points without arrowheads illustrate inferred trends for individual eruptive centers.

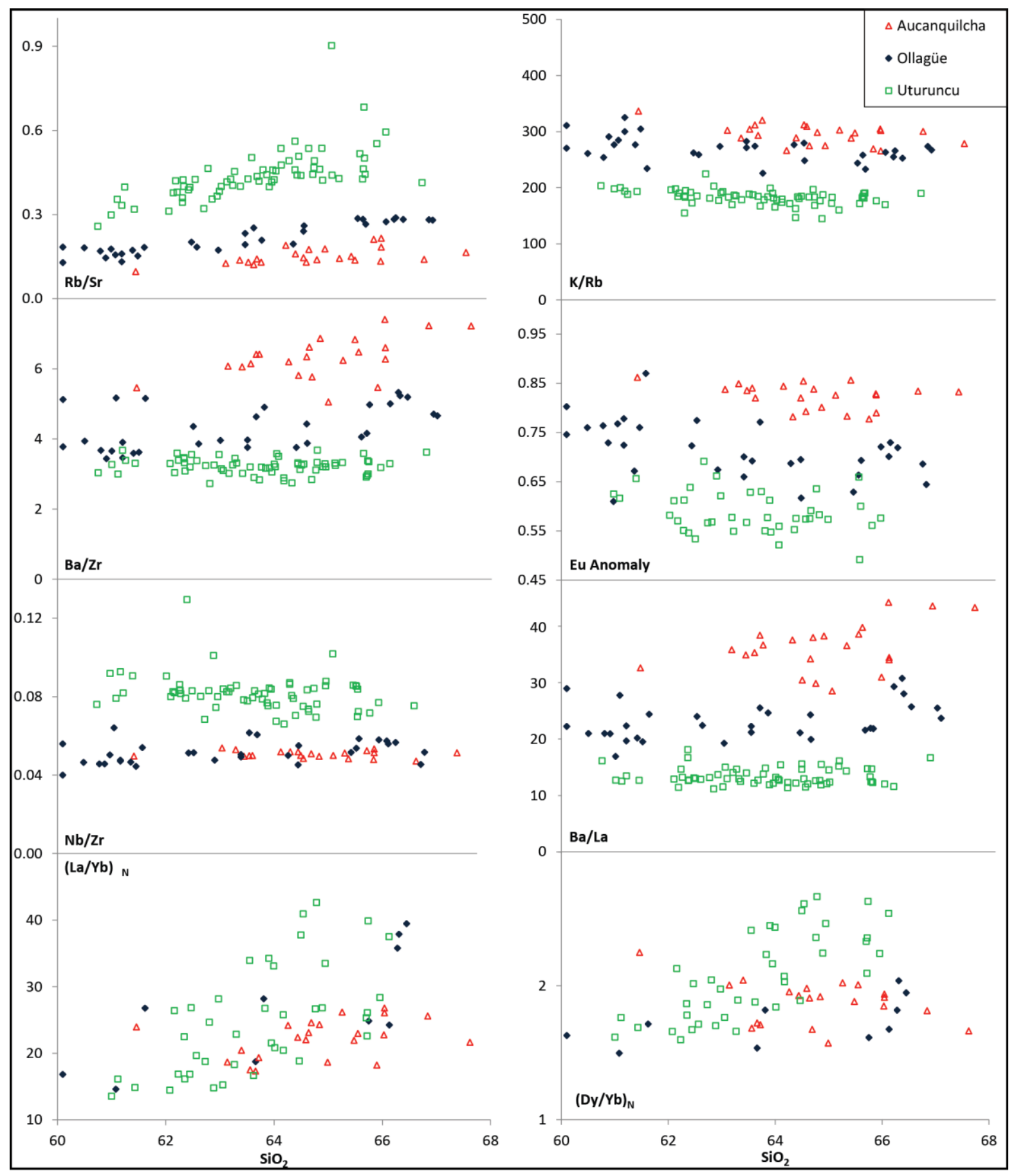


Figure 8. Plots of trace element ratios for Aucanquilcha, Ollagüe, and Uturuncu rocks $v s$. $\mathrm{Y}$, La contents and $\mathrm{La} / \mathrm{Yb}$ ratios.

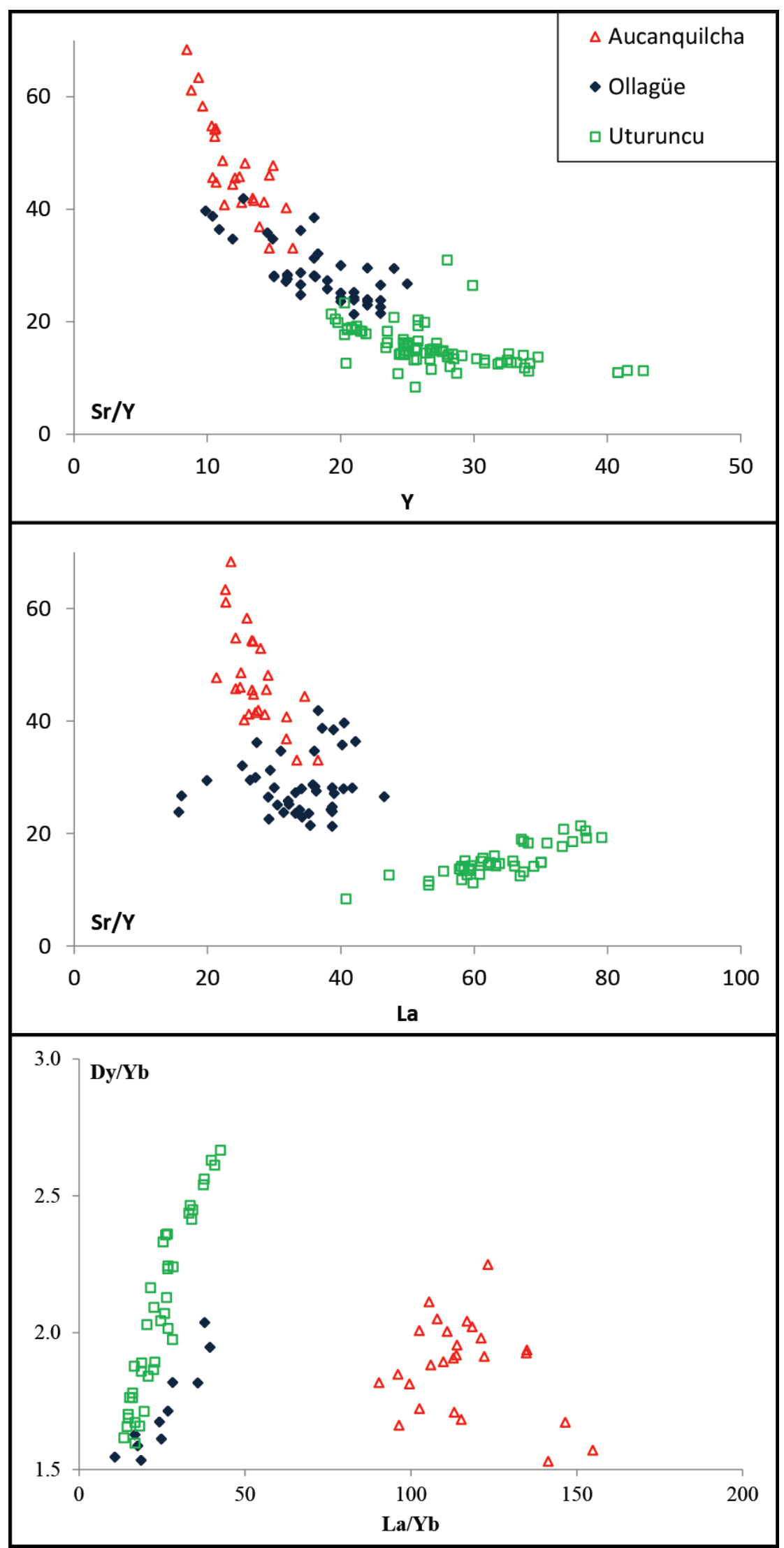


Figure 9. Plots of ${ }^{87} \mathrm{Sr} /{ }^{86} \mathrm{Sr},{ }^{143} \mathrm{Nd} /{ }^{144} \mathrm{Nd}$, and ${ }^{18} \mathrm{O} /{ }^{16} \mathrm{O}$ (as $\delta^{18} \mathrm{O}$ values of mineral separates) ratios of Aucanquilcha, Ollagüe and Uturuncu rocks vs. $\mathrm{SiO}_{2}$. Lines through data points illustrate inferred trends for individual eruptive centers.

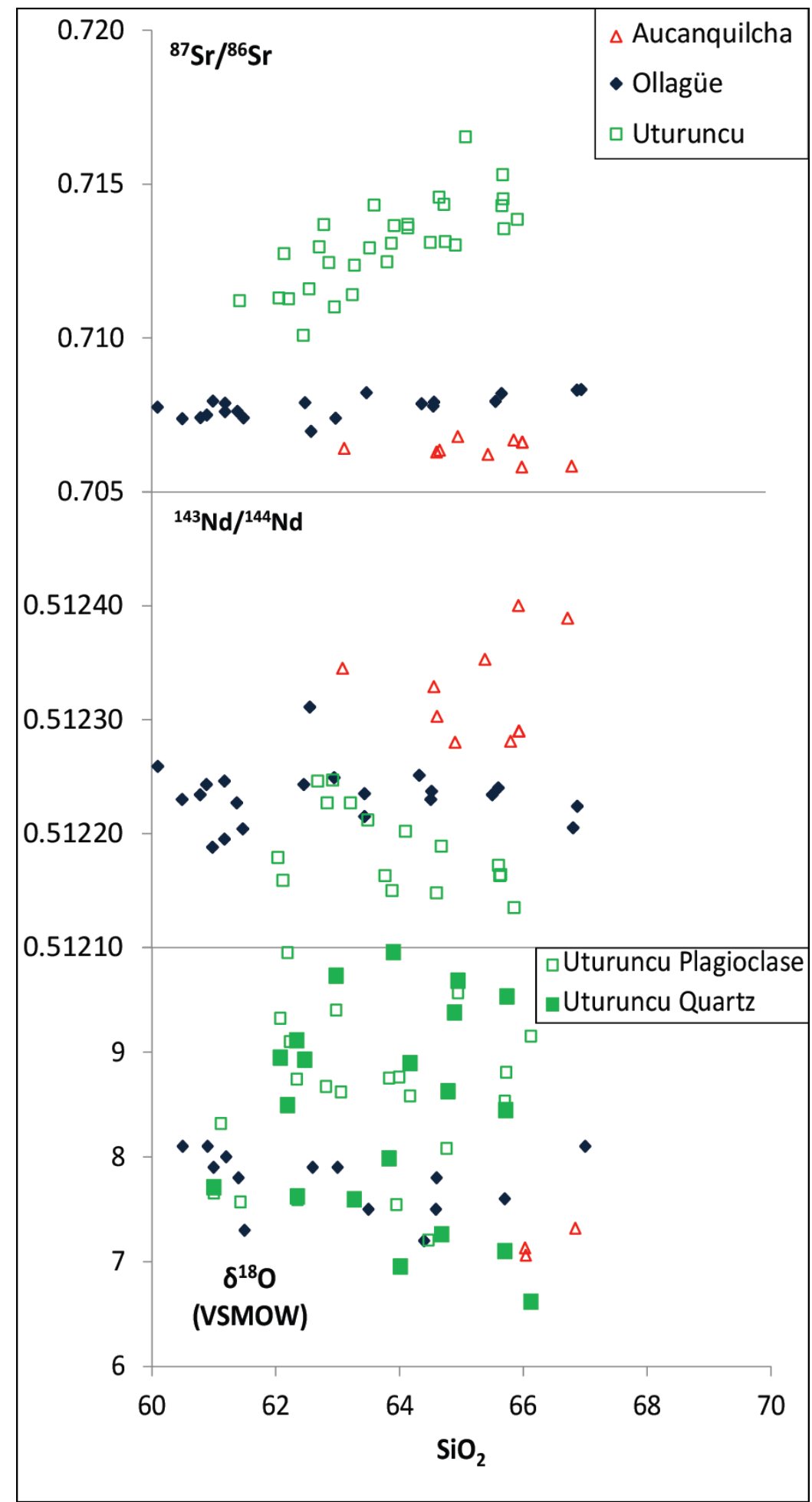


Figure 10. (a) ${ }^{143} \mathrm{Nd} /{ }^{144} \mathrm{Nd} v s .{ }^{87} \mathrm{Sr} /{ }^{86} \mathrm{Sr}$ ratios of Aucanquilcha, Ollagüe and Uturuncu rocks. Arrow labeled BE illustrates direction toward position of "Bulk Earth", which plots off of figure; (b) ${ }^{87} \mathrm{Sr} /{ }^{86} \mathrm{Sr}$ vs. Sr/Y ratios of Aucanquilcha, Ollagüe and Uturuncu rocks.

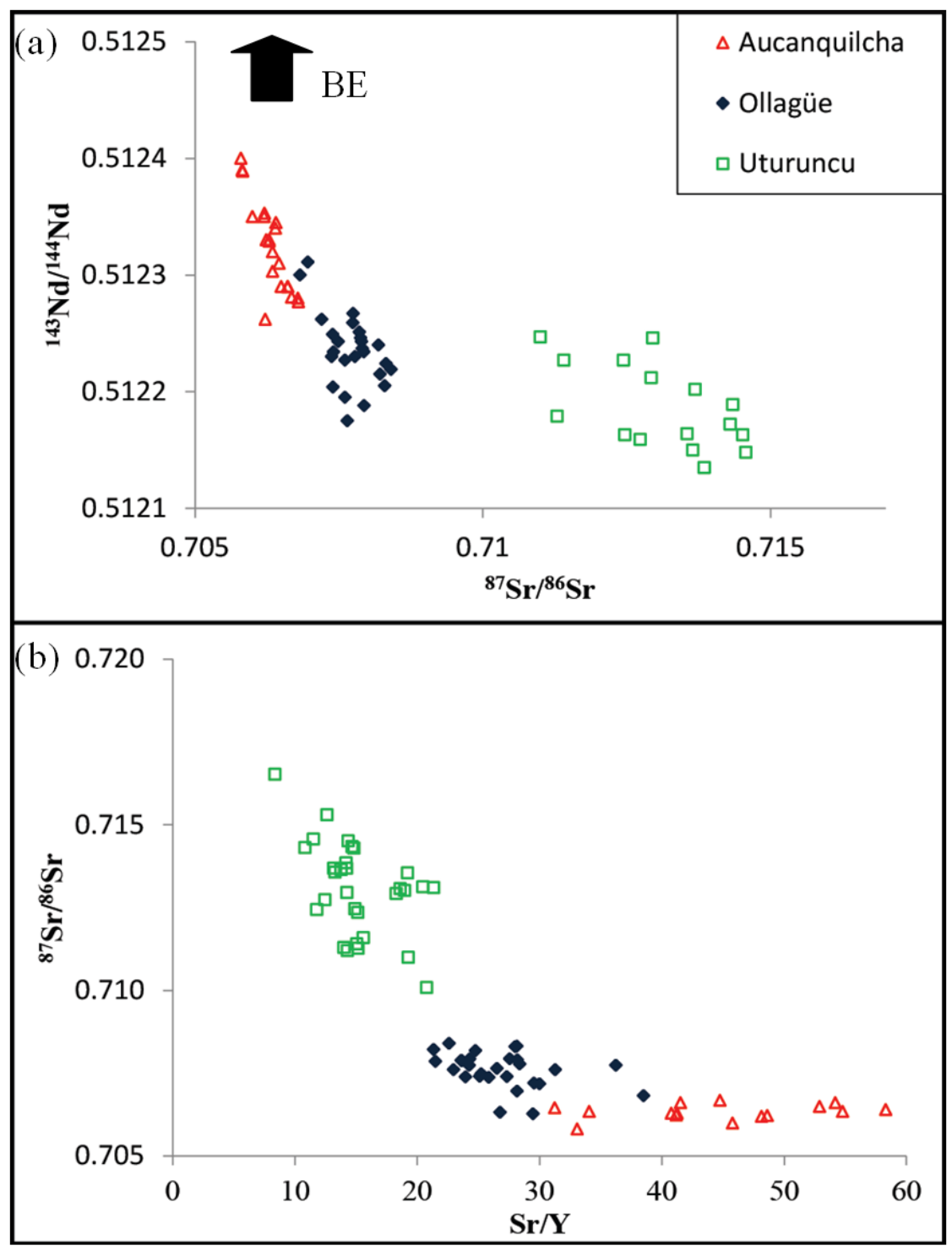

Rocks from Aucanquilcha and Ollagüe have extremely variable $\mathrm{Pb}$ isotopic ratios and show no distinct arrays with varying $\mathrm{SiO}_{2}$ concentrations (not shown). Uturuncu rocks (Table 3) have very restricted ${ }^{207} \mathrm{~Pb} /{ }^{204} \mathrm{~Pb},{ }^{208} \mathrm{~Pb} /{ }^{204} \mathrm{~Pb}$, and ${ }^{206} \mathrm{~Pb} /{ }^{204} \mathrm{~Pb}$ ratios, although they are higher on average than for Ollagüe or Aucanquilcha rocks (Figure 11).

$\mathrm{Pb}$ isotopic ratios for all three centers lie within the southern sector $\mathrm{Pb}$ isotopic domain defined by Wörner et al. [22]. Aucanquilcha and Ollagüe $\mathrm{Pb}$ isotopic values lie in the Southern Altiplano $\mathrm{Pb}$ isotopic domains $\left({ }^{207} \mathrm{~Pb} /{ }^{204} \mathrm{~Pb}>15.64,{ }^{208} \mathrm{~Pb} /{ }^{204} \mathrm{~Pb}<38.89\right.$ but $>38.5$ and $\left.{ }^{206} \mathrm{~Pb} /{ }^{204} \mathrm{~Pb}>18.6\right)$ defined by Aitcheson et al. [87] and Uturuncu lies within the Eastern Cordilleran domain $\left({ }^{207} \mathrm{~Pb} /{ }^{204} \mathrm{~Pb}>15.64\right.$, ${ }^{208} \mathrm{~Pb} /{ }^{204} \mathrm{~Pb}>38.9$ and $\left.{ }^{206} \mathrm{~Pb} /{ }^{204} \mathrm{~Pb}>18.6\right)$. 
Figure 11. ${ }^{208} \mathrm{~Pb} /{ }^{204} \mathrm{~Pb} v$ s. ${ }^{206} \mathrm{~Pb} /{ }^{204} \mathrm{~Pb}$ and ${ }^{207} \mathrm{~Pb} /{ }^{204} \mathrm{~Pb} v$ s. ${ }^{206} \mathrm{~Pb} /{ }^{204} \mathrm{~Pb}$. Pb isotopic ratios for all three centers lie within the southern Altiplano $\mathrm{Pb}$ isotopic domain defined by Wörner et al. [22] and Aitcheson et al. [87]. Grey field defines the boundary between the Eastern Cordilleran domain and the Southern Altiplano domain [87].

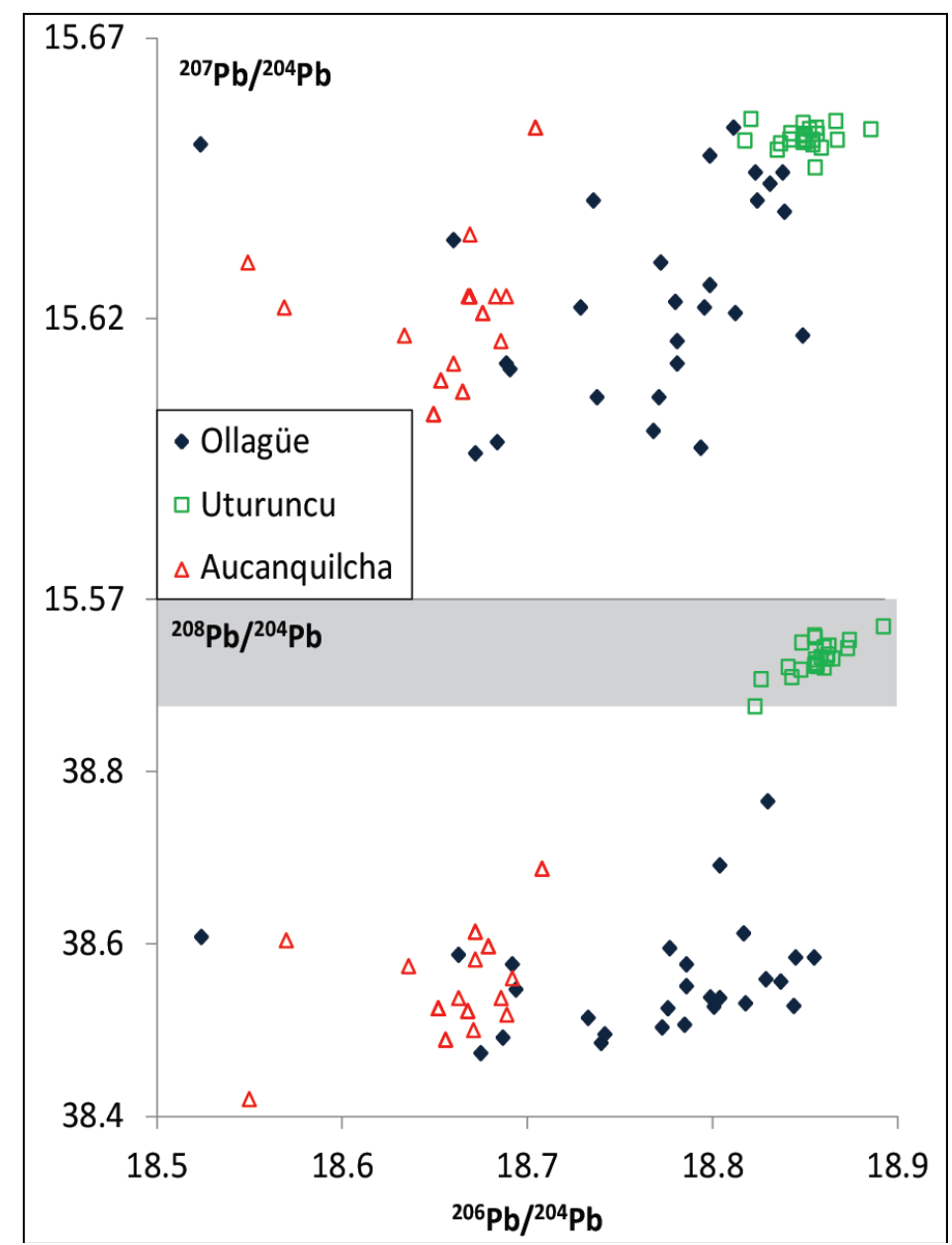

\section{Discussion: Origin of Across-Arc Geochemical Variations in the Central Andes at} $21^{\circ}-22^{\circ} \mathrm{S}$ Latitude

Major and trace element across-arc variations at $21^{\circ}-22^{\circ} \mathrm{S}$ latitude described in the previous section are similar in several respects to trends observed at many other convergent margin settings where there is thin (Southern Andes) or no overlying continental crust (oceanic arcs; as described by Gill [2]; p. 209, and Tatsumi and Eggins [4]; pp. 80-81). These include increases in $\mathrm{K}_{2} \mathrm{O}$ and most incompatible trace elements with increasing distance from the active arc front. Notable exceptions are that whole rock $\mathrm{Na}_{2} \mathrm{O}, \mathrm{Sr}$, and $\mathrm{Ba}$ contents decrease to the east for a given $\mathrm{SiO}_{2}$ concentration (Figures 4 and 5). These trends are contrary to the across-arc behavior of these elements observed at other oceanic arcs (e.g., New Zealand, Java, Japan, and the Aleutians; [2-5,88]).

It has been repeatedly demonstrated that $\mathrm{K}$ and incompatible trace elements tend to increase in arc magmas with distance behind the volcanic front (there is, however, no general rule for isotopic ratios [2-5,89]). Much of our perspective on the origin of these trends comes from study of intra-oceanic arcs or arcs constructed over young, thin continental crust [6,90-92]. In these settings, 
across-arc geochemical trends are nearly always linked to systematic changes in mantle source compositions, degrees of partial melting, and, or, slab dehydration reactions. This is because they are typically expressed in the most primitive rocks of any given suite and they frequently correlate with other petrologic features such as inferred primary magmatic $\mathrm{H}_{2} \mathrm{O}$ contents [11,12,93-95].

The Andean CVZ offers the opposite perspective to island arcs: thick continental crust producing or enhancing across-arc trace element variations in subduction zone magmas. A result of the anomalously thick crust beneath the $\mathrm{CVZ}$ is that the across-arc increases in $\mathrm{K}_{2} \mathrm{O}$ and incompatible trace element concentrations do not directly reflect variations in mantle source compositions or degrees of partial melting. Baseline $\mathrm{Sr}$ and $\mathrm{O}$ isotopic ratios of the volcanic rocks are highly elevated relative to primitive intra-oceanic arc magmas, implying a contribution from the continental crust during magma petrogenesis [96]. Furthermore, ${ }^{87} \mathrm{Sr} /{ }^{86} \mathrm{Sr}$ and ${ }^{18} \mathrm{O} /{ }^{16} \mathrm{O}$ ratios become more variable and increase towards the east for a given $\mathrm{SiO}_{2}$ concentration while ${ }^{143} \mathrm{Nd} /{ }^{144} \mathrm{Nd}$ ratios decrease (Figure 9). These trends parallel the incompatible trace element trends for each of the three volcanic centers (Figures 5-7). This suggests that the sources become more variable/complex towards the east. The thick continental crust thus modifies primary arc magmas generated across the transect (Figures 10 and 11), yet many of the universal across-arc trace element trends observed at oceanic arcs are maintained (Figure 5). How is this possible?

A variety of models have been proposed to account for the across-arc trace element trends at $21^{\circ}-22^{\circ} \mathrm{S}$ latitude. However, until recently these models have been difficult to test due to the absence of a comprehensive data set on magmas erupted from suitable back-arc locations. This is important in order to constrain the processes and contaminants that influence magmatic differentiation to a singular location rather than using multiple locations that may have undergone different processes or assimilated different crustal contaminants. Using data from multiple centers representing a "zone" would require additional analyses and comparison of the centers. Fernández et al. [42], Kussmaul et al. [44], Avila-Salinas [38], and Feeley [41] demonstrated that rocks with the highest $\mathrm{K}_{2} \mathrm{O}$ contents also have the highest ${ }^{87} \mathrm{Sr} /{ }^{86} \mathrm{Sr}$ ratios. These authors proposed that the eastward enrichments of incompatible trace elements require the involvement of some form of crustal melting or contamination. Further to the south, Kay et al. [17] suggested that the ignimbrites located on the Puna plateau are controlled by basement contaminants during the earliest stages of volcanism. Overtime, this contribution diminishes and compositions become increasingly controlled by mantle source compositions. Fernández et al. [42] and Kussmaul et al. [44] suggested that the observed compositional trends may reflect crustal melting or contamination of more mafic magmas at increasingly shallower depths eastward. These conclusions were reached without comprehensive trace element data, which was later suggested to play key roles in modeling the mineralogies and source compositions during magma differentiation and migration [41,97,98]. Avila-Salinas [38] suggested the trends may reflect an eastward increase in the degree of upper-crustal contamination, although little evidence was discussed to support this idea. Feeley [41] argued the trends may reflect assimilation of progressively less hybridized mid-deep crustal rocks eastward (e.g., Figure 5). Diminishing hybridization of the continental crust east of the volcanic front was inferred to reflect diminishing intrusion of subduction-derived basaltic magmas due to progressively lower degrees of mantle partial melting. In contrast to these models, Dostal et al. [99] suggested a more traditional model where the across-arc spatial variations were attributed to the degree of mantle partial melting with increasing depths to the Benioff zone and possibly systematic variations 
in mantle source compositions as a result of hydrous fluid fluxing. The temporal geochemical evolution of the Central Andes was discussed by Mamani et al. [36,37]. These authors used $\mathrm{Sr} / \mathrm{Y}$, $\mathrm{Dy} / \mathrm{Yb}$ and $\mathrm{Sm} / \mathrm{Yb}$ to describe changes in arc magma composition from the Triassic to the recent and discussed the observed changes these ratios have during arc migration. These authors suggested that along-strike variations from $18^{\circ}$ to $28^{\circ} \mathrm{S}$ over time were caused by the onset of crustal thickening and changes in the depth of assimilation at $\sim 30 \mathrm{Ma}$ and again at $\sim 3 \mathrm{Ma}$. The variation caused by the onset of crustal thickening at $\sim 30 \mathrm{Ma}$ resulted in higher ratios of $\mathrm{Dy} / \mathrm{Yb}$ and $\mathrm{Sm} / \mathrm{Yb}$ reflecting increased lithospheric pressures at the time of differentiation and crust-magma interaction. These depths were suggested to be where garnet and amphibole are stable [37].

The model by Kay et al. [17] is a hybrid model. In the early stages of eruption of the Puna ignimbrites the composition of the ignimbrites are controlled by variation in the crustal composition. Over time, these authors suggest that the composition of the crust becomes less important, and the controlling factor in the compositional variation between the back arc and the arc front volcanic rocks is variation in the mantle source and slab fluxes. Early stages of this model suggest hybridization and crustal assimilation similar to the model presented by Feeley [41], but does not suggest how geochemical variation occurs at a single point in time. The model of Kay et al. [17] requires a temporal component to observe similar across arc variations seen at $21^{\circ}-22^{\circ}$.

Our preferred explanation for the across-arc geochemical and isotopic trends described in the previous section is that magmas assimilate continental crust that becomes increasingly more mafic toward the arc-front because of relatively recent intrusion and hybridization by primary, subduction-derived basaltic magmas. Several lines of evidence collectively support this hypothesis. First, the curvilinear array formed by ${ }^{87} \mathrm{Sr} /{ }^{86} \mathrm{Sr}$ and ${ }^{143} \mathrm{Nd} /{ }^{144} \mathrm{Nd}$ ratios on Figure 10 , with magmas becoming isotopically more crustal-like with increasing distance from the arc front, cannot reflect a continuous differentiation trend formed by a common petrogenetic process given the similar bulk compositions (i.e., $\mathrm{SiO}_{2}$ and $\mathrm{MgO}$ contents) of the rocks at the three centers (a similar argument can be made for the across-arc trend in $\mathrm{Sr} v s$. O isotope ratios). Instead, it is more likely related to local isotopic differences in the composition of the mid- deep-continental crust. In this regard, it is possible that magmas at Uturuncu assimilated crustal rocks similar in composition to un-hybridized Paleozoic granites and gneisses exposed in northwestern Argentina. These rocks have ${ }^{87} \mathrm{Sr} /{ }^{86} \mathrm{Sr}$ ratios between 0.71 and 0.80 [100-104]. Assimilation fractional crystallization modeling of Uturuncu magmatic inclusions and contaminants of similar composition to the Paleozoic granites described by Lucassen $[36,37,73,100,102,103,105-110]$ suggest that very little contamination is required to produce the high $\mathrm{Sr}$ isotopic ratios while maintaining the moderate $\mathrm{Sr}$ concentrations observed at Uturuncu. Increasing $\mathrm{Rb} / \mathrm{Sr}$ ratios (Figure 7) toward the east can thus be directly related to assimilation of progressively older, less-hybridized crustal rocks toward the east with high ${ }^{87} \mathrm{Sr} /{ }^{86} \mathrm{Sr}$ ratios due to protracted in-growth of radiogenic ${ }^{87} \mathrm{Sr}$ in assimilated lithologies.

Second, across-arc increases in $\mathrm{K}_{2} \mathrm{O}, \mathrm{Rb}, \mathrm{Th}, \mathrm{Y}, \mathrm{REE}$ and HFSE contents can be interpreted to reflect assimilation of more silicic lithologies with higher incompatible trace element contents in which residual mineralogies are progressively more feldspar-rich. In the latter regard it is important to note that contrary to across-arc geochemical trends commonly observed at other arcs, the CVZ rocks display systematically lower $\mathrm{Na}_{2} \mathrm{O}, \mathrm{CaO}, \mathrm{Al}_{2} \mathrm{O}_{3}, \mathrm{Sr}$, and $\mathrm{Ba}$ contents toward the east; stoichiometric components or trace elements with relatively high partition coefficients in feldspar-rich assemblages [83]. Furthermore, 
with increasing distance from the arc-front, the rocks have progressively more negative Eu anomalies (Figure 7), also consistent with more feldspar-rich residual mineralogies. In a similar manner, across-arc increases in $\delta^{18} \mathrm{O}$ can be interpreted to indicate assimilation of rocks with increasingly higher proportions of more silicic, ${ }^{18} \mathrm{O}$-concentrating minerals toward the east.

Third, more feldspar-rich residual mineralogies toward the east are supported by experimental studies. Specifically, Huang and Wyllie [111] demonstrated in tonalite melting experiments at low- $\mathrm{H}_{2} \mathrm{O}$ and high pressures $(\sim 15 \mathrm{kbar})$, similar to conditions assumed for the mid-deep crust beneath the southern $\mathrm{CVZ}$, that $\mathrm{K}_{2} \mathrm{O}$-rich silicic melts are produced with residual plagioclase and garnet. In contrast, during melting of mafic amphibolite under similar conditions, plagioclase becomes unstable, increasing Sr concentrations in the melt [20,98]. Moreover, high-pressure (e.g., $\geq 15 \mathrm{kbar}$ ) melting experiments by Litvinovsky et al. [112] on a variety of Archean silicic rock compositions (e.g., charnokite, granodiorite, and leuco-granite) under both wet and fluid-absent conditions in all cases produced silicic melts in equilibrium with residual garnet, Na-rich feldspar, and clinopyroxene. At low to moderate melt fractions (e.g., 5\%-25\%), derivative melts are characterized by low $\mathrm{Na}_{2} \mathrm{O}$, but high $\mathrm{K}_{2} \mathrm{O}$ contents. Collectively, these experiments demonstrate that partial melting of mafic protoliths at high pressures leads to production of melts with high $\mathrm{Sr} / \mathrm{Y}$ ratios, whereas high pressure melting of more silicic compositions leads to production of melts with low $\mathrm{Sr} / \mathrm{Y}$ ratios (largely due to low $\mathrm{Sr}$ contents) and $\mathrm{Na}_{2} \mathrm{O}$ contents, but high $\mathrm{K}_{2} \mathrm{O}$ contents. The smooth, curvilinear array on Figure 8 with $\mathrm{Sr} / \mathrm{Y}$ ratios decreasing with increasing $\mathrm{Y}$ contents to the east is therefore consistent with a progressive change to melting of more silicic bulk composition crustal rocks eastward and more feldspar-rich residual mineralogies (alternatively, this trend has also been ascribed to melting at progressively lower pressures in the absence of residual garnet, but we discount this below).

Kay et al. [17] suggested that the low $\mathrm{Na}_{2} \mathrm{O}$ concentrations observed in the Puna ignimbrites (Grandada-Orosmayo, Panizos, and Vilama) combined with high ${ }^{87} \mathrm{Sr} /{ }^{86} \mathrm{Sr}$ ratios $(0.709861-0.715048 ;[113,114])$ and $\delta^{18} \mathrm{O}(9.05-10.24$; [113,114]) ratios are the result of crustal contamination by old shale-like components with similar interpretations for the Altiplano ignimbrites (e.g., Morococala; [115]). This is a possible alternative to the model described above, but still supports the model that the composition of the continental crust changes eastward.

Finally, observations by Baker and Francis [53] indicate that the greatest volumes of late Cenozoic, subduction-related rocks are located along the arc-front and decrease systematically toward the east. This may indicate that recent intrusion of subduction-derived mafic melts has been greatest in the mid- to deep-crust beneath the arc front and diminishes in a regular manner toward the east. A straightforward interpretation of this result is that the continental crust is likely younger and more mafic beneath the arc-front as a result of hybridization due to protracted intrusion of subduction-derived, primary basaltic magmas. A further implication of the higher magma volumes along the arc-front is that the degree of mantle partial melting and thus melt production may be greatest along the arc-front.

We discount other models to explain the observed across-arc geochemical trends. For example, Fernández et al. [42] and Kussmaul et al. [44] suggested the trends may reflect crustal melting or contamination of more mafic magmas at increasingly shallower depths eastward. This hypothesis is unlikely because $\mathrm{Y}$ and $\mathrm{Yb}$ contents, although high in Uturuncu rocks, probably as a result of assimilation of more incompatible element-enriched silicic crustal source rocks, decrease with 
increasing $\mathrm{SiO}_{2}$ contents for rocks from all centers (Figure 5). This suggests that garnet was in the high-pressure melt residue after assimilation for all three suites, consistent with the experimental studies cited above involving a wide-range of crustal source rock compositions [17]. Furthermore, with increasing $\mathrm{SiO}_{2}$ contents, $(\mathrm{La} / \mathrm{Yb})_{n}$ ratios increase for rocks from all centers and broadly overlap or are higher in Uturuncu rocks, consistent with similar amounts of garnet in the residue during crustal melting for all centers and, by extension, comparable depths of differentiation (Figure 7; [116]). This is also consistent with the similar petrographic features of the rocks from all centers, which indicates comparable petrogenetic histories. There is thus no evidence for shallower depths of melting toward the east. In contrast, with increasing $\mathrm{SiO}_{2}$ contents, $(\mathrm{Dy} / \mathrm{Yb})_{n}$ ratios (calculated by the method of [116]) decrease in Aucanquilcha rocks, are roughly constant for the Ollagüe suite, and increase for Uturuncu rocks (Figure 7). Similar trends are seen for $\mathrm{TiO}_{2} v s . \mathrm{SiO}_{2}$ for rocks from Aucanquilcha and Uturuncu (Figure 4). Furthermore, $\mathrm{FeO}$ contents increase eastward at a given $\mathrm{SiO}_{2}$ content. Collectively these trends can be explained by more mafic, Ti- amphibole-rich lithologies (and residual mineralogies) in the mid-deep crust beneath the arc-front relative to the mid- to deep-crust beneath the back-arc, given that partition coefficients for middle-REE (e.g., Dy) are higher than for heavy-REE (e.g., Yb) in amphibole (see [116,117]). As a result, the trend of smoothly decreasing Sr/Y ratios with increasing Y contents and increasing $\mathrm{Eu}$ anomalies from west to east (Figures 5 and 8) are best explained by assimilation in the mid- to deep-crust of progressively more felsic, incompatible trace element enriched crustal compositions (e.g., [118]), as opposed to progressively shallower depths of assimilation.

The presence of plagioclase, either in the source as a residual phase or as a result of fractionation during melt migration, plays a key role in controlling the variations observed in the Sr contents for all three centers. By normalizing Sr to an element such as $\mathrm{Y}$ we can observe the effects of plagioclase in the source or during melt migration. The increasing Eu anomalies observed from west to east suggest that beneath the arc front plagioclase is neither retained in the source or fractionated during melt migration. This can be explained by either the stability of plagioclase in the melt or in the source. As suggested by the middle-REE patterns for rocks from Aucanquilcha, a mafic amphibole-rich source explains why fractionation or retention of plagioclase is not observed in either the $\mathrm{Sr} / \mathrm{Y}$ ratio or the Eu anomaly for these rocks. In contrast, at Uturuncu more pronounced Eu anomalies, lower $\mathrm{Sr} / \mathrm{Y}$ ratios and middle-REE patterns are observed suggesting fractionation or retention of plagioclase is present either in the source or during migration of the melt.

$\mathrm{La} / \mathrm{Ta}$ ratios show little correlation with distance from the arc front at $21^{\circ}-22^{\circ} \mathrm{S}$ similar to the model proposed by Kay et al. [17] for the Puna ignimbrites. When Ba/Ta ratios are compared to Ta concentrations for the three centers, the highest $\mathrm{Ba} / \mathrm{Ta}$ ratios coincide with the lowest $\mathrm{Ta}$ concentrations (Figure 12). Uturuncu rocks for a given $\mathrm{SiO}_{2}$ have lower $\mathrm{Ba}$ concentrations than observed at Aucanquilcha. This relationship further supports the inference made from the $\mathrm{Sr} / \mathrm{Y}$ ratios that the source beneath Uturuncu is compositionally different than beneath Aucanquilcha. Ba/Ta ratios for Ollagüe overlap with both Uturuncu and Aucanquilcha suggesting that the variation may be more controlled by the Ta concentration of the rocks than the Ba concentration. 
Figure 12. $\mathrm{Ba} / \mathrm{Ta}$ ratios $v s . \mathrm{La} / \mathrm{Ta}$ ratios. The $\mathrm{Ba} / \mathrm{La}$ ratio for rocks sampled at the three centers decreases with distance from the arc front. The grey shaded area labeled arc are the lower limits of ratios among $\mathrm{La}, \mathrm{Ba}$ and $\mathrm{Ta}$ in mafic southern Andean volcanic arc rocks as interpreted by Hickey et al. [82] as inferred from Kay et al. [17]. Ratios observed at Uturuncu are similar to ratios observed by Kay et al. [17] for northern Puna small volume ignimbrites.

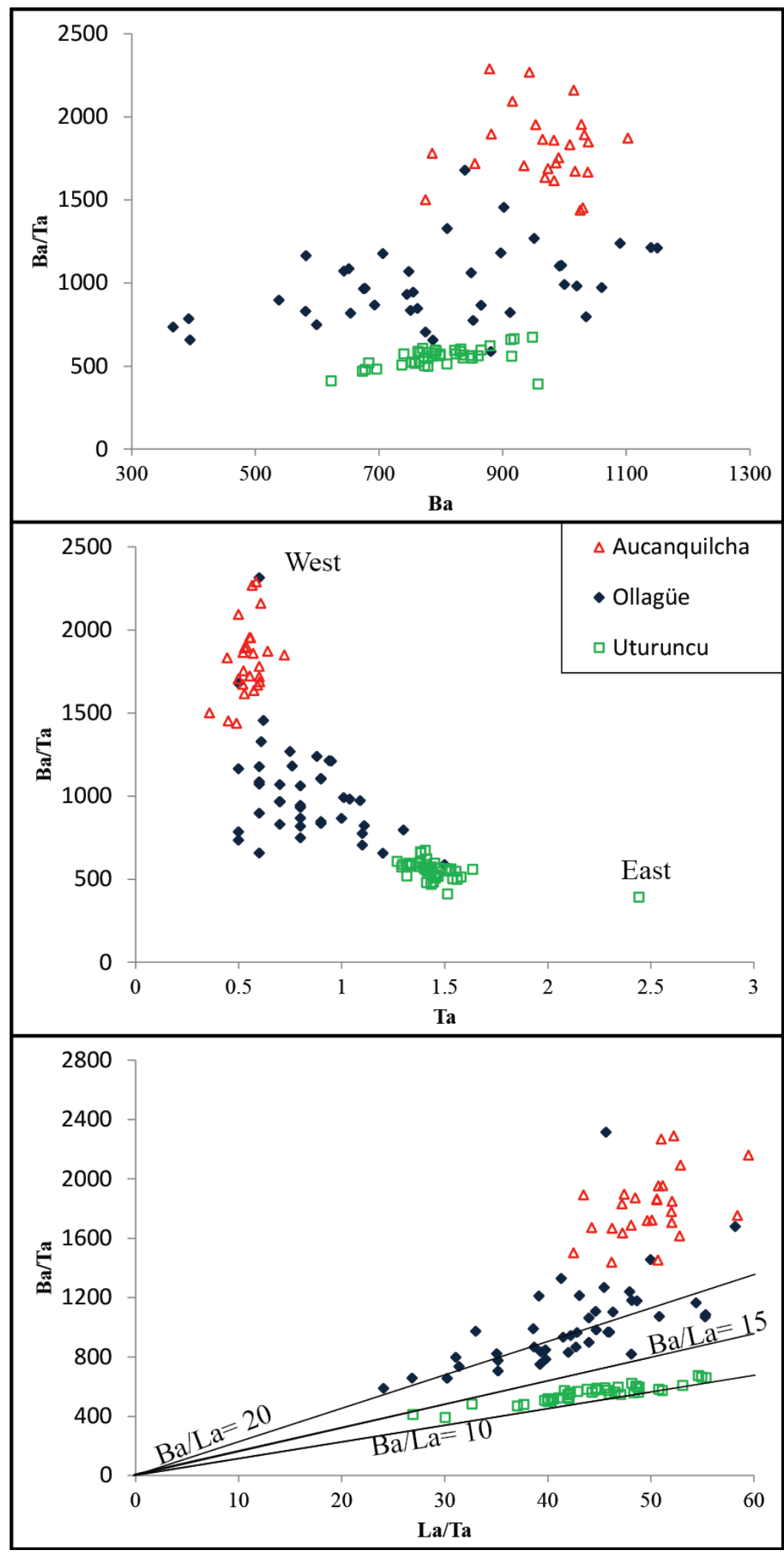


Finally, Dostal et al. [99] suggested a more traditional model to explain the across-arc geochemical variations at $21^{\circ}-22^{\circ} \mathrm{S}$ latitude. This model is similar in many respects to models often invoked for oceanic island arc settings or arcs constructed over thin continental crust [6,94,118]. Specifically, Dostal et al. [99] suggested that the proportion of a LILE-enriched hydrous fluid added to the mantle source region for the volcanic rocks decreases across the strike of the arc. Ultimately, this fluid is derived from the subducting, dehydrating Nazca plate. Concomitant with the across-arc decrease in the proportion of a slab-derived fluid is a decrease in the degree of mantle partial melting. This suggestion stems from the well-documented decrease in mantle solidus temperatures with progressive hydration (e.g., [119-121]). This model is initially attractive because it can account for the strongly west to east decreasing primary magma production rates as reflected in decreasing eruption volumes of the composite cones at $21^{\circ}-22^{\circ} \mathrm{S}$ latitude. This, of course, assumes that magma production rates in the mantle and eruption rates at the surface correlate with the degree of mantle partial melting.

The geochemical implications of decreasing west to east fluid fluxing are two-fold. First, because contents of trace elements with low crystal/liquid partition coefficients (e.g., LILE, REE, HFSE) in primary basaltic melts are a strong function of the degree of partial melting of the mantle source, primary melts generated behind the arc-front will have progressively higher contents of incompatible elements, relative to arc-front magmas, because they derive from smaller degrees of partial melting (this accounts for the K- $h$ relationship). Second, superposed on these first-order variations will be across-arc variations in the LILE contents of the mantle source due to their selective transport and enrichment in slab-derived hydrous fluids [12,122,123]. The LILE enrichments are highest at the arc-front where the proportion of fluid is greatest and they diminish behind the arc. The net effect of these two processes is to produce primary melts with relatively low incompatible trace element contents but high LILE/HFSE and LILE/REE along the arc-front where the mantle is fluxed by larger amounts of slab-derived fluid and partially melts to a greater extent than behind the arc (e.g., [8]). Further, there may also be additional complexities introduced by inherent across-arc variations in mantle source compositions, particularly radiogenic isotopic ratios, prior to or during slab dehydration- or melt-related metasomatism [124].

Any subcrustal model such as that described above is inherently difficult to test and quantitatively model, given the strongly crustal isotopic compositions of the volcanic rocks at $21^{\circ}-22^{\circ} \mathrm{S}$ latitude and lack of knowledge of deep-crustal compositions in the CVZ. Interaction of the silicic magmas with thick continental crust is thus expected to mask most of the influence of the slab dehydration fluids and any pre-metasomatic isotopic variations [118]. Geochemical variations consistent with such a model include lower LILE/HFSE and LILE/REE ratios at a given $\mathrm{SiO}_{2}$ content toward the east at the three centers (Figure 7). However, in more detail this model cannot account for numerous other features such as lower $\mathrm{Na}_{2} \mathrm{O}, \mathrm{Ba}$, and $\mathrm{Sr}$ contents (Figures 4 and 5) and higher $\mathrm{Sr} / \mathrm{Y}$ (where $\mathrm{Sr}$ is considered to be more fluid-mobile than $\mathrm{Y}$ ) and ${ }^{18} \mathrm{O} /{ }^{16} \mathrm{O}$ ratios (Figure 8) ratios in Uturuncu rocks relative to those erupted on or slightly behind the arc-front. A subcrustal model invoking an across-arc variation in degrees of mantle partial melting also cannot account for relatively high $\mathrm{Nb} / \mathrm{Zr}$ ratios in Uturuncu rocks relative to those at Aucanquilcha and Ollagüe, as the degrees of incompatibility between $\mathrm{Nb}$ and $\mathrm{Zr}$ in mantle solid assemblages are very small $\left(\mathrm{D}_{\mathrm{Nb}}\right.$ and $\mathrm{D}_{\mathrm{Zr}}$ are estimated to be 0.04 and 0.08 , respectively; [125]). Thus, this ratio is not expected to vary strongly with different degrees of mantle partial melting and is instead controlled by the crustal contaminant. Therefore, although decreasing 
degrees of mantle partial melting with increased distance from the arc front are expected to produce geochemical variations in parental magmas at $21^{\circ}-22^{\circ} \mathrm{S}$ latitude (i.e., [126]), we consider the across-arc geochemical and isotopic variations documented for silicic rocks in this study to be largely, if not mostly, crustal in origin. We acknowledge, however, that the more "arc-like" nature (e.g., higher LILE/HFSE ratios) of the silicic rocks erupted on or just east of the arc-front may, in fact, partially reflect greater volumetric intrusion of primary mafic magmas with high LILE/HFSE beneath the arc-front relative to the back-arc, lowering the compositional distinctions between primary magmas and the arc-front crust with time.

Wörner et al. [22] and Harmon et al. [127] observed similar along-strike geochemical trends within the CVZ to the across strike trends. The northern CVZ has been shown to be more radiogenic compared to the south. These authors proposed that this relationship is a function of thicker crust and varying composition of the crust beneath the arc front of the northern CVZ compared to the southern CVZ. Across-arc geochemical variation at $21^{\circ}-22^{\circ} \mathrm{S}$ latitude shows a similar relationship to the along-arc variations described by previous authors [22,36,37,96,128] in that variation in the continental crust composition and thickness of the crust is expressed in the volcanic products with increasing distance away from the arc front. Toward the east as the continental crust thickens the volcanic rocks record more radiogenic isotopic signatures inherited from the assimilation of older, less hybridized basement rocks. The source rock composition at the arc-front is less radiogenic as a direct result of intrusion of mafic magmas during the formation of the modern arc-front.

\section{Broader Implications}

An intriguing result of this study is that on first inspection across-arc geochemical variations at volcanic arcs constructed over thick continental crust, such as increasing $\mathrm{K}_{2} \mathrm{O}$ and incompatible trace element contents, resemble those observed at island arcs and arcs constructed over thin continental crust. However, on closer inspection there are significant differences, particularly involving systematic variations in isotopic ratios and other geochemical features that reflect interaction with variable composition continental crust with distance from the arc-front. This contrasts with the results of studies of island arcs where the occurrence of $\mathrm{K}_{2} \mathrm{O}$-rich magmas in back-arc regions is often ascribed to decreasing additions of slab-derived, LILE-rich hydrous fluids to mantle source regions with concomitant decreases in the degree of mantle partial melting and volumetric production of primary mafic magmas. However, we argue based on the geochemical data presented in this paper and geologic relationships [53] that although across-arc geochemical variations at island arcs and arcs constructed over thick continental crust are produced by apparently fundamentally different processes, ultimately they are both related, directly and indirectly, respectively, to mantle processes associated with the subduction process itself. Specifically, at continental volcanic arcs greater time-integrated primary melt production beneath frontal arc regions has the potential to produce younger, more mafic crustal compositions due to repeated intrusion and hybridization by primary mantle-derived melts. Smaller degrees of mantle partial melting and volumetric melt production in back arc regions results in progressively less hybridized or modified continental crust that retains to a larger degree its more silicic, isotopically evolved composition. Production of intermediate to silicic composition magmas in continental arcs with more "arc-like" chemical (e.g., higher LILE/HFSE) and isotopic features (lower 
${ }^{87} \mathrm{Sr} /{ }^{86} \mathrm{Sr}$ ) in frontal-arc localities relative to back-arc magmas is therefore ultimately linked to higher degrees of mantle partial melting and melt production, as is inferred for island arcs as well. Thus, although subduction zone magmas may be substantially modified by the continental crust resulting in systematic across-arc geochemical trends, these trends are a manifestation that the continental crust has also been substantially modified by fundamental subduction zone processes similar to those proposed for island arcs. In short, the crust thus modifies the compositions of subduction zone magmas, but complimentary to this, subduction zone magmas modify the composition of the continental crust.

\section{Conclusions}

In an effort to better understand the origin of systematic across-arc geochemical variations in silicic volcanic rocks (60-68 wt \% $\mathrm{SiO}_{2}$ ) from the Andean Central Volcanic Zone, we compared geochemical and isotopic compositions of Quaternary $(<1.0 \mathrm{Ma})$ lava flows erupted at three well-characterized composite volcanoes situated along a narrow southeast striking transect between $21^{\circ}$ and $22^{\circ} \mathrm{S}$. Trends observed include the following. At a given $\mathrm{SiO}_{2}$ content lavas erupted with increasing distance from the arc-front display systematically higher $\mathrm{K}_{2} \mathrm{O}, \mathrm{P}_{2} \mathrm{O}_{5}, \mathrm{TiO}_{2}, \mathrm{Rb}, \mathrm{Th}, \mathrm{Y}, \mathrm{REE}$ and HFSE contents; $\mathrm{Rb} / \mathrm{Sr}$ elemental ratios; and $\mathrm{Sr}$ and $\mathrm{O}$ isotopic ratios. In contrast, the lavas display systematically lower $\mathrm{Al}_{2} \mathrm{O}_{3}, \mathrm{Na}_{2} \mathrm{O}, \mathrm{Sr}$, and $\mathrm{Ba}$ contents; $\mathrm{Ba} / \mathrm{Nb}, \mathrm{K} / \mathrm{Rb}$, and $\mathrm{Sr} / \mathrm{Y}$ elemental ratios; and $\mathrm{Nd}$ isotopic ratios. In addition, $\mathrm{Eu}$ anomalies become progressively more negative toward the east.

These variations are interpreted to indicate that mid- to deep-crustal source rocks for the lavas become progressively older and more feldspar-rich with increasing distance from the arc front. In this regard, silicic magmas erupted along the arc-front reflect melting of relatively young, mafic composition amphibolitic source rocks with garnet-rich, but feldspar-poor residual mineralogies. Towards the east, the lower crust becomes increasingly older with a more felsic bulk composition in which residual mineralogies are progressively more feldspar-rich. The implication of this interpretation is that large-scale regional trends in magma compositions at continental volcanic arcs may reflect a process wherein the continental crust becomes strongly hybridized beneath frontal arc localities due to protracted intrusion of subduction-derived basaltic magmas, with a diminishing effect behind the arc front because of smaller degrees of mantle partial melting and primary melt generation.

\section{Acknowledgments}

The authors wish to thank Frank Ramos for use of and assistance with the thermal ionization mass spectrometer at New Mexico State University; Peter Larson at Washington State University for assistance with the O-isotope analyses; Shan de Silva, Duncan Muir, and all members of the PLUTONS working group for insightful discussions; Jamie Kern for field assistance; and the residents of Quetena Chico, Bolivia, and Lipiko Tours for logistical support and hospitality. We thank three anonymous reviews for detailed comments that substantially improved this manuscript. We also thank David Foster for efficient handling of this paper. This work was supported by U.S. National Science Foundation grant EAR-0901148 to TCF and grants to GSM from the Department of Earth Sciences at Montana State University. 


\section{Conflicts of Interest}

The authors declare no conflict of interest.

\section{References}

1. Dickinson, W.R.; Hatherton, T. Andesitic volcanism and seismicity around pacific. Science 1967, 157, 801-803.

2. Gill, J.B. Orogenic Andesites and Plate Tectonics; Springer-Verlag: Berlin, Germany, 1981.

3. Jakes, P.; White, A.J.R. Major and trace-element abundances in volcanic-rocks of orogenic areas. Geol. Soc. Am. Bull. 1972, 83, 29-40.

4. Tatsumi, Y.; Eggins, S. Subduction Zone Magmatism; Blackwell Science: Oxford, UK, 1995.

5. Dickinson, W.R. Potash-depth $(\mathrm{K}-h)$ relations in continental-margin and intra-oceanic magmatic arcs. Geology 1975, 3, 53-56.

6. Churikova, T.; Dorendorf, F.; Worner, G. Sources and fluids in the mantle wedge below Kamchatka, evidence from across-arc geochemical variation. J. Petrol. 2001, 42, 1567-1593.

7. Feeley, T.C. Origin and tectonic implications of across-strike geochemical variations in the Eocene Absaroka volcanic province, United States. J. Geol. 2003, 111, 329-346.

8. Hickey-Vargas, R.; Roa, H.M.; Escobar, L.L.; Frey, F.A. Geochemical variations in Andean basaltic and silicic lavas from the Villarrica-Lanin volcanic chain $\left(39.5^{\circ} \mathrm{S}\right)$ : An evaluation of source heterogeneity, fractional crystallization and crustal assimilation. Contrib. Mineral. Petrol. 1989, 103, 361-386.

9. Leeman, W.P.; Smith, D.R.; Hildreth, W.; Palacz, Z.; Rogers, N. Compositional diversity of Late Cenozoic basalts in a transect across the southern Washington Cascades: Implications for subduction zone magmatism. J. Geophys. Res. Solid 1990, 95, 19561-19582.

10. Patino, L.C.; Carr, M.J.; Feigenson, M.D. Cross-arc geochemical variations in volcanic fields in Honduras CA: Progressive changes in source with distance from the volcanic front. Contrib. Mineral. Petrol. 1997, 129, 341-351.

11. Ryan, J.G.; Morris, J.; Tera, F.; Leeman, W.P.; Tsvetkov, A. Cross-arc geochemical variations in the Kurile Arc as a function of slab depth. Science 1995, 270, 625-627.

12. Stolper, E.; Newman, S. The role of water in the petrogenesis of Mariana Trough magmas. Earth Planet. Sci. Lett. 1994, 121, 293-325.

13. Walker, J.A.; Carr, M.J.; Patino, L.C.; Johnson, C.M.; Feigenson, M.D.; Ward, R.L. Abrupt change in magma generation processes across the Central-American arc in southeastern Guatemala: Flux dominated melting near the base of the wedge to decompression melting near the top of the wedge. Contrib. Mineral. Petrol. 1995, 120, 378-390.

14. Coira, B.; Kay, S.M. Implications of Quaternary volcanism at Cerro Tuzgle for crustal and mantle evolution of the Puna Plateau, Central Andes, Argentina. Contrib. Mineral. Petrol. 1993, $113,40-58$.

15. Caffe, P.J.; Trumbull, R.B.; Coira, B.L.; Romer, R.L. Petrogenesis of Early Neogene magmatism in the northern Puna; Implications for magma genesis and crustal processes in the Central Andean Plateau. J. Petrol. 2002, 43, 907-942. 
16. Kay, S.M.; Mpodzis, C.; Coria, B. Neogene Magmatism, Tectonism, and Mineral Deposits of the Central Andes (22 $2^{\circ}$ to $33^{\circ} \mathrm{S}$ Latitude). In Geology and Ore Deposits of the Central Andes; Skinner, B.J., Ed.; Society of Economic Geologists: Littleton, CO, USA, 1999; pp. 27-59.

17. Kay, S.M.; Coira, B.L.; Caffe, P.J.; Chen, C.H. Regional chemical diversity, crustal and mantle sources and evolution of Central Andean Puna Plateau ignimbrites. J. Volcanol. Geotherm. Res. 2010, 198, 81-111.

18. Schnurr, W.B.W.; Trumbull, R.B.; Clavero, J.; Hahne, K.; Siebel, W.; Gardeweg, M. Twenty-five million years of silicic volcanism in the southern Central Volcanic Zone of the Andes: Geochemistry and magma genesis of ignimbrites from $25^{\circ}$ to $27^{\circ} \mathrm{S}, 67^{\circ}$ to $72^{\circ} \mathrm{W}$. J. Volcanol. Geotherm. Res. 2007, 166, 17-46.

19. Trumbull, R.D.; Wittenbrink, R.; Hahne, K.; Emmermann, R.; Busch, W.; Gerstenberger, H.; Siebel, W. Evidence for Late Miocene to recent contamination of arc andesites by crustal melts in the Chilean Andes $\left(25-26^{\circ} \mathrm{S}\right)$ and its geodynamic implications. J. S. Am. Earth Sci. 1999, 12, $135-155$.

20. Hildreth, W.; Moorbath, S. Crustal contributions to arc magmatism in the Andes of central Chile. Contrib. Mineral. Petrol. 1988, 98, 455-489.

21. Plank, T.; Langmuir, C.H. An evaluation of the global variations in the major element chemistry of arc basalts. Earth Planet. Sci. Lett. 1988, 90, 349-370.

22. Worner, G.; Moorbath, S.; Harmon, R.S. Andean Cenozoic volcanic centers reflect basement isotopic domains. Geology 1992, 20, 1103-1106.

23. Feeley, T.C. Volcan Ollagüe: Volcanology, Petrology and Geochemistry of a Major Quaternary Stratovolcano in the Andean Central Volcanic Zone. Ph.D. Thesis, University of California, Los Angeles, CA, USA, June 1993.

24. Feeley, T.C.; Clynne, M.A.; Winer, G.S.; Grice, W.C. Oxygen isotope geochemistry of the Lassen Volcanic Center, California: Resolving crustal and mantle contributions to continental arc magmatism. J. Petrol. 2008, 49, 971-997.

25. Feeley, T.C.; Davidson, J.P. Petrology of calc-alkaline lavas at Volcan Ollagüe and the origin of compositional diversity at Central Andean stratovolcanoes. J. Petrol. 1994, 35, 1295-1340.

26. Feeley, T.C.; Sharp, Z.D. ${ }^{18} \mathrm{O} /{ }^{16} \mathrm{O}$ isotope geochemistry of silicic lava flows erupted from Volcan Ollagüe, Andean Central Volcanic Zone. Earth Planet. Sci. Lett. 1995, 133, 239-254.

27. Grunder, A.L.; Klemetti, E.W.; Feeley, T.C.; McKee, C.M. Eleven million years of arc volcanism at the Aucanquilcha volcanic cluster, northern Chilean Andes: Implications for the life span and emplacement of plutons. Trans. Roy. Soc. Ed. Earth 2006, 97, 415-436.

28. Allmendinger, R.W.; Jordan, T.E.; Kay, S.M.; Isacks, B.L. The evolution of the Altiplano-Puna Plateau of the Central Andes. Annu. Rev. Earth Planet. Sci. 1997, 25, 139-174.

29. Beck, S.L.; Zandt, G.; Myers, S.C.; Wallace, T.C.; Silver, P.G.; Drake, L. Crustal-thickness variations in the Central Andes. Geology 1996, 24, 407-410.

30. James, D.E. Plate Tectonic model for evolution of Central Andes. Geol. Soc. Am. Bull. 1971, 82, 3325-3346.

31. Schmitz, M.; Heinsohn, W.D.; Schilling, F.R. Seismic, gravity and petrological evidence for partial melt beneath the thickened Central Andean crust (21-23 S). Tectonophysics 1997, 270, 313-326. 
32. Beck, S.L.; Zandt, G. The nature of orogenic crust in the Central Andes. J. Geophys. Res. Solid Earth 2002, 107, doi:10.1029/2000JB000124.

33. McGlashan, N.; Brown, L.; Kay, S.M. Crustal thickness in the Central Andes from teleseismically recorded depth phase precursors. Geophys. J. Int. 2008, 175, 1013-1022.

34. Yuan, X.; Sobolev, S.V.; Kind, R.; Oncken, O.; Bock, G.; Asch, G.; Schurr, B.; Graeber, F.; Rudloff, A.; Hanka, W.; et al. Subduction and collision processes in the Central Andes constrained by converted seismic phases. Nature 2000, 408, 958-961.

35. Yuan, X.; Sobolev, S.V.; Kind, R. Moho Topography in the Central Andes and its geodynamic implications. Earth Planet. Sci. Lett. 2002, 199, 389-402.

36. Mamani, M.; Tassara, A.; Woerner, G. Composition and structural control of crustal domains in the Central Andes. Geochem. Geophys. Geosyst. 2008, 9, doi:10.1029/2007GC001925.

37. Mamani, M.; Worner, G.; Sempere, T. Geochemical variations in igneous rocks of the Central Andean orocline $\left(13^{\circ} \mathrm{S}\right.$ to $\left.18^{\circ} \mathrm{S}\right)$ : Tracing crustal thickening and magma generation through time and space. Geol. Soc. Am. Bull. 2010, 122, 162-182.

38. Avila-Salinas, W. Petrological and Tectonic Evolution of Cenozoic Volcanism in the Bolivian Western Andes. In Andean Magmatism and Its Tectonic Setting; Geological Society of America Special Paper; Harmon, R.S., Rapela, C.W., Eds.; Geological Society of America: Boulder, CO, USA, 1991; Volume 265, pp. 245-258.

39. Deruelle, B. Calc-alkaline and shoshonitic lavas from 5 Andean volcanos (between latitudes $21^{\circ} 45^{\prime} \mathrm{S}$ and $24^{\circ} 30^{\prime} \mathrm{S}$ ) and distribution of Plio-Quaternary volcanism of south-Central and Southern Andes. J. Volcanol. Geotherm. Res. 1978, 3, 281-298.

40. Du Bray, E.A.; Ludington, S.; Brooks, W.E.; Gamble, B.M.; Ratte, J.C.; Richter, D.H.; Soria-Escalante, E. Compositional Characteristics of Middle to Upper Tertiary Volcanic Rocks of the Bolivian Altiplano; U.S. Geological Survey: Reston, VA, USA, 1995.

41. Feeley, T.C. Crustal modification during subduction-zone magmatism: Evidence from the southern Salar De Uyuni region $\left(20^{\circ}-22^{\circ} \mathrm{S}\right)$, Central Andes. Geology 1993, 21, 1019-1022.

42. Fernandez, C.; Horman, P.K.; Kussmaul, S.; Meave, J.; Pichler, H.; Subieta, T. First petrologic data on young volcanic rocks of SW-Bolivia. Tsch. Mineral. Petrogr. Mitt. 1973, 19, 149-172.

43. Klerkx, J.; Deutsch, S.; Pichler, H.; Zeil, W. Strontium isotopic composition and trace-element data bearing on origin of Cenozoic volcanic-rocks of Central and Southern Andes. J. Volcanol. Geotherm. Res. 1977, 2, 49-71.

44. Kussmaul, S.; Hormann, P.K.; Ploskonka, E.; Subieta, T. Volcanism and structure of southwestern Bolivia. J. Volcanol. Geotherm. Res. 1977, 2, 73-111.

45. Thorpe, R.S.; Francis, P.W. Variations in Andean andesite compositions and their petrogenetic significance. Tectonophysics 1979, 57, 53-70.

46. Lamb, S.H.; Hoke, L.; Kennan, L.; Dewey, J. Cenozoic Evolution of the Central Andes in Bolivia and Northern Chile. In Orogeny Through Time; Geological Society Special Publication No. 121; Burg, J.P., Ford, M., Eds.; The Geologic Society: London, UK, 1997; pp. 237-264.

47. Feeley, T.C.; Hacker, M.D. Intracrustal derivation of Na-rich andesitic and dacitic magmas: An example from Volcan Ollagüe, Andean Central Volcanic Zone. J. Geol. 1995, 103, 213-225. 
48. Sparks, R.S.J.; Folkes, C.B.; Humphreys, M.C.S.; Barfod, D.N.; Clavero, J.; Sunagua, M.C.; McNutt, S.R.; Pritchard, M.E. Uturuncu Volcano, Bolivia: Volcanic unrest due to mid-crustal magma intrusion. Am. J. Sci. 2008, 308, 727-769.

49. De Silva, S.L.; Francis, P.W. Volcanoes of the Central Andes; Springer-Verlag: New York, NY, USA, 1991.

50. Zandt, G.; Leidig, M.; Chmielowski, J.; Baumont, D.; Yuan, X.H. Seismic detection and characterization of the Altiplano-Puna Magma Body, Central Andes. Pure Appl. Geophys. 2003, 160, 789-807.

51. De Silva, S.L.; Zandt, G.; Trumbull, R.; Viramonte, J.; Salas, G.; Jiminez, N. Large Ignimbrite Eruptions and Volcano-Tectonic Depressionsin the Central Andes: A Thermomechanical Perspective. In Mechanisms of Activity and Unrest at Large Calderas; Geological Society Special Publication No. 269; Troise, C., De Natale, G., Kilburn, C.R.J., Eds.; The Geologic Society: London, UK, 2006; pp. 47-63.

52. De Silva, S.L. Altiplano-Puna Volcanic Complex of the Central Andes. Geology 1989, 17, 1102-1106.

53. Baker, M.C.W.; Francis, P.W. Upper Cenozoic volcanism in Central Andes-Ages and volumes. Earth Planet. Sci. Lett. 1978, 41, 175-187.

54. Gradstein, F.M.; Ogg, J.G.; Smith, A.G. A Geologic Time Scale 2004; Cambridge University Press: Cambridge, UK, 2004.

55. Somoza, R.; Ghidella, M.E. Convergencia en el margen occidental de América del Sur durante el Cenozoico: Subducción de las Placas de Nazca, Farallon y Phoenix. Rev. Assoc. Geol. Argent. 2005, 60, 797-809, (in Spanish).

56. Somoza, R.; Ghidella, M.E. Late Cretaceous to recent plate motioins in western South America revisited. Earth Planet. Sci. Lett. 2012, 331-332, 152-163.

57. Gregory-Wodzicki, K.M. Uplift history of the Central and Northern Andes: A review. Bull. Geol. Soc. Am. 2000, 112, 1091-1105.

58. Isacks, B.L. Uplift of the Central Andean Plateau and bending of the Bolivian orocline. J. Geophys. Res. Solid 1988, 93, 3211-3231.

59. Kay, S.M.; Coira, B.L.; Kay, R.W. Central Andean Galan Ignimbrites: Magma evolution from the mantle to eruption in a thickened crust. Geochim. Cosmochim. Acta 2009, 73, A630.

60. Klemetti, E.W.; Grunder, A.L. Volcanic evolution of Volcan Aucanquilcha: A long-lived dacite volcano in the Central Andes of northern Chile. Bull. Volcanol. 2008, 70, 633-650.

61. Klemetti, E.W. Constraining the Magmatic Evolution of the Andean Arc at $21^{\circ} \mathrm{S}$ Using the Volcanic and Petrologic History of Volcán Aucanquilcha, Central Volcanic Zone, Northern Chile. Ph.D. Thesis, Oregon State University, Corvalis, OR, USA, February 2005.

62. Simkin, T.; Siebert, S.L. Volcanoes of the World: a Regional Directory, Gazetteer, and Chronology of Volcanism During the Last 10,000 Years; Geosciences Press: Tucson, AZ, USA, 1994.

63. Feeley, T.C.; Davidson, J.P.; Armendia, A. The volcanic and magmatic evolution of Volcan Ollagüe, a high-K, Late Quaternary stratovolcano in the Andean Central Volcanic Zone. J. Volcanol. Geotherm. Res. 1993, 54, 221-245. 
64. Worner, G.; Lezaun, J.; Beck, A.; Heber, V.; Lucassen, F.; Zinngrebe, E.; Rossling, R.; Wilke, H.G. Precambrian and Early Paleozoic evolution of the Andean basement at Belen (northern Chile) and Cerro Uyarani (western Bolivia Altiplano). J. S. Am. Earth Sci. 2000, 13, $717-737$.

65. Clavero, J.; Polanco, E.; Godoy, E.; Aguilar, G.; Sparks, R.S.J.; van Wykde Vries, B.; Pérez de Arce, C.; Matthews, S. Substrata influence in the transport and emplacement mechanism of the Ollagüe debris avalanche (northern Chile). Acta Vulcanol. 2004, 16, 59-76.

66. Vezzoli, L.; Tibaldi, A.; Renzulli, A.; Menna, M.; Flude, S. Faulting-assisted lateral collapses and influence on shallow magma feeding systems at Ollagüe volcano (Central Volcanic Zone, Chile-Bolivia Andes). J. Volcanol. Geotherm. Res. 2008, 171, 137-159.

67. Johnson, D.M.; Hooper, P.R.; Conrey, R.M. XRF Analysis of rocks and minerals for major and trace elements on a single low dilution Li-tetraborate fused bead. Adv. X-Ray Anal. 1999, 41, 843-867.

68. Jarvis, K.E. Inductively coupled plasma mass-spectrometry: A new technique for the rapid or ultra-trace level determination of the rare-earth elements in geological-materials. Chem. Geol. 1988, 68, 31-39.

69. Ramos, F.C.; Reid, M.R. Distinguishing melting of heterogeneous mantle sources from crustal contamination: Insights from $\mathrm{Sr}$ isotopes at the phenocryst scale, Pisgah Crater, California. J. Petrol. 2005, 46, 999-1012.

70. Todt, W.; Cliff, R.A.; Hanser, A.; Hofmann, A.W. Evaluation of a ${ }^{202} \mathrm{~Pb}-{ }^{205} \mathrm{~Pb}$ Double Spike for High-Precision Lead Isotope Analysis. In Earth Processes: Reading the Isotope Code; Hart, S.R., Basu, A., Eds.; American Geophysical Union: Washington, DC, USA, 1996; Volume 95, pp. 429-437.

71. Takeuchi, A.; Larson, P.B. Oxygen isotope evidence for the Late Cenozoic development of an orographic rain shadow in eastern Washington, USA. Geology 2005, 33, 313-316.

72. Valley, J.W.; Kitchen, N.; Kohn, M.J.; Niendorf, C.R.; Spicuzza, M.J. UWG-2, A garnet standard for oxygen isotope ratios: Strategies for high precision and accuracy with laser heating. Geochim. Cosmochim. Acta 1995, 59, 5223-5231.

73. Michelfelder, G.S.; Feeley, T.C.; Wilder, A.D.; Thacker, J. Mixing Following Assimilation-Fractional Crystallization at Cerro Uturuncu, Andean Central Volcanic Zone, SW Bolivia as Revealed from in Situ Laser Ablation Isotopic Analysis of Plagioclase. In Proceedings of International Association of Volcanology and Chemistry of the Earth's Interior (IAVCEI) 2013 Scientific Assembly, Kagoshima, Japan, 20-24 July 2013; pp. 1847-1841.

74. Muir, D.D.; Blundy, J.; Hutchinson, M.C.; Rust, A.C. Petrological imaging of an active pluton beneath Cerro Uturuncu, Bolivia. Contrib. Mineral. Petrol. 2013, submitted for publication.

75. Fialko, Y.; Pearse, J. Sombrero uplift above the Altiplano-Puna Magma Body: Evidence of a ballooning mid-crustal diapir. Science 2012, 338, 250-252.

76. Henderson, S.T.; Pritchard, M.E. Decadal volcanic deformation in the Central Andes Volcanic Zone revealed by InSAR time series. Geochem. Geophys. Geosyst. 2013, 14, 1358-1374. 
77. Jay, J.A.; Pritchard, M.E.; West, M.E.; Christensen, D.; Haney, M.; Minaya, E.; Sunagua, M.; McNutt, S.R.; Zabala, M. Shallow seismicity, triggered seismicity, and ambient noise tomography at the long-dormant Uturuncu Volcano, Bolivia. Bull. Volcanol. 2012, 74, 817-837.

78. Walker, B.A., Jr.; Klemetti, E.W.; Grunder, A.L.; Dilles, J.H.; Tepley, F.J.; Gile, D. Crystal reaming during the assembly, maturation, and waning of an eleven-million-year crustal magma cycle: Thermobarometry of the Aucanquilcha Volcanic Cluster. Contrib. Mineral. Petrol. 2013, $165,663-682$.

79. Mattioli, M.; Renzulli, A.; Menna, M.; Holm, P.M. Rapid ascent and contamination of magmas through the thick crust of the CVZ (Andes, Ollague region): Evidence from a nearly aphyric high-K andesite with skeletal olivines. J. Volcanol. Geotherm. Res. 2006, 158, 87-105.

80. Le Maitre, R.W. Igneous Rocks, A Classification and Glossary of Terms; Cambridge University Press: Cambridge, UK, 2002.

81. Sun, S.S.; McDonough, W.F. Chemical and isotopic systematics of oceanic basalts: Implications for mantle compositions and processes. Geol. Soc. Lond. Spec. Publ. 1989, 42, 313-345.

82. Hickey, R.L.; Frey, F.A.; Gerlach, D.C.; Lopez-Escobar, L. Multiple sources for basaltic arc rocks from the Southern Volcanic Zone of the Andes $\left(34^{\circ}-41^{\circ} \mathrm{S}\right)$ : Trace element and isotopic evidence for contributions from subducted oceanic crust, mantle, and continental crust. J. Geophys. Res. Solid Earth 1986, 91, 5963-5983.

83. Rollinson, H.R. Using Geochemical Data: Evaluation, Presentation, Interpretation; John Wiley and Sons: New York, NY, USA, 1993.

84. Bindeman, I.N.; Eiler, J.M.; Yogodzinski, G.M.; Tatsumi, Y.; Stern, C.R.; Grove, T.L.; Portnyagin, M.; Hoernle, K.; Danyushevsky, L.V. Oxygen isotope evidence for slab melting in modern and ancient subduction zones. Earth Planet. Sci. Lett. 2005, 235, 480-496.

85. Bindeman, I.N.; Ponomareva, V.V.; Bailey, J.C.; Valley, J.W. Volcanic arc of Kamchatka: A province with high- $\delta{ }^{18} \mathrm{O}$ magma sources and large-scale ${ }^{18} \mathrm{O} /{ }^{16} \mathrm{O}$ depletion of the upper crust. Geochim. Cosmochim. Acta 2004, 68, 841-865.

86. Valley, J.W. Stable isotope thermometry at high temperatures. Rev. Mineral. Geochem. 2001, 43, $365-413$.

87. Aitcheson, S.J.; Harmon, R.S.; Moorbath, S.; Schneider, A.; Soler, P.; Soriaescalante, E.; Steele, G.; Swainbank, I.; Worner, G. Pb isotopes define basement domains of the Altiplano, Central Andes. Geology 1995, 23, 555-558.

88. Elburg, M.A.; van Bergen, M.; Hoogewerff, J.; Foden, J.; Vroon, P.; Zulkarnain, I.; Nasution, A. Geochemical trends across an arc-continent collision zone: Magma sources and slab-wedge transfer processes below the Pantar Strait Volcanoes, Indonesia. Geochim. Cosmochim. Acta 2002, 66, 2771-2789.

89. Dreher, S.T.; Macpherson, C.G.; Pearson, D.G.; Davidson, J.P. Re-Os isotope studies of Mindanao Adakites: Implications for sources of metals and melts. Geology 2005, 33, 957-960.

90. Ayers, J. Trace element modeling of aqueous fluid-Peridotite interaction in the mantle wedge of subduction zones. Contrib. Mineral. Petrol. 1998, 132, 390-404.

91. Brenan, J.M.; Shaw, H.F.; Ryerson, F.J.; Phinney, D.L. Mineral-aqueous fluid partitioning of trace-elements at $900{ }^{\circ} \mathrm{C}$ and $2.0 \mathrm{GPa}$ - Constraints on the trace-element chemistry of mantle and deep-crustal fluids. Geochim. Cosmochim. Acta 1995, 59, 3331-3350. 
92. Schmidt, M.W.; Poli, S. Experimentally based water budgets of dehydrating slabs and consequencesfor arc magma generation. Earth Planet. Sci. Lett. 1998, 163, 361-379.

93. Danyushevsky, L.V.; Falloon, T.J.; Sobolev, A.V.; Crawford, A.J.; Carroll, M.; Price, R.C. The $\mathrm{H}_{2} \mathrm{O}$ content of basalt glasses from southwest Pacific back-arc basins. Earth Planet. Sci. Lett. 1993, 117, 347-362.

94. Newman, S.; Stolper, E.; Stern, R. $\mathrm{H}_{2} \mathrm{O}$ and $\mathrm{CO}_{2}$ in magmas from the Mariana arc and back arc systems. Geochem. Geophys. Geosyst. 2000, 1, doi:10.1029/1999GC000027.

95. Shibata, T.; Nakamura, E. Across-arc variations of isotope and trace element compositions from Quaternary basaltic volcanic rocks in northeastern Japan: Implications for interaction between subducted oceanic slab and mantle wedge. J. Geophys. Res. Solid Earth 1997, 102, 8051-8064.

96. Davidson, J.P.; Hannon, R.S.; Womer, G. The Source of Central Andean Magmas: Some Considerations. In Andean Magmatism and Its Tectonic Setting; Hannon, R.S., Rapela, C.W., Eds.; Geological Society of America: Denver, CO, USA, 1991; pp. 825-843.

97. Hawkesworth, C.J.; Clarke, C.B. Partial Melting in the Lower Crust: New Constraints on Crustal Contamination Processes in the Central Andes. In Tectonics of the Southern Central Andes; Reutter, K.J., Scheurber, E., Wigger, P.J., Eds.; Springer-Verlag: New York, NY, USA, 1994; pp. 93-101.

98. Sen, C. Subduction Related Petrologic Processes: 1-Dehydration Melting of a Basaltic Composition Amphibolites. 2-Mantle Metasomatism. Ph.D. Thesis, University of New Brunswick, New Brunswick, Canada, February 1994.

99. Dostal, J.; Zentilli, M.; Caelles, J.C.; Clark, A.H. Geochemistry and origin of volcanic-rocks of Andes $\left(26^{\circ}-28^{\circ}\right.$ S). Contrib. Mineral. Petrol. 1977, 63, 113-128.

100. Lucassen, F.; Becchio, R.; Wilke, H.G.; Franz, G.; Thirlwall, M.F.; Viramonte, J.; Wemmer, K. Proterozoic-Paleozoic development of the basement of the Central Andes (18-26 $\mathrm{S})$-A mobile belt of the South American craton. J. S. Am. Earth Sci. 2000, 13, 697-715.

101. Lucassen, F.; Franz, G.; Laber, A. Permian high pressure rocks-The basement of the Sierra de Limon Verde in northern Chile. J. S. Am. Earth Sci. 1999, 12, 183-199.

102. Lucassen, F.; Kramer, W.; Bartsch, V.; Wilke, H.G.; Franz, G.; Romer, R.L.; Dulski, P. Nd, Pb, and $\mathrm{Sr}$ isotope composition of juvenile magmatism in the Mesozoic large magmatic province of northern Chile $\left(18^{\circ}-27^{\circ} \mathrm{S}\right)$ : Indications for a uniform subarc mantle. Contrib. Mineral. Petrol. 2006, 152, 571-589.

103. Lucassen, F.; Lewerenz, S.; Franz, G.; Viramonte, J.; Mezger, K. Metamorphism, isotopic ages and composition of lower crustal granulite xenoliths from the Cretaceous Salta Rift, Argentina. Contrib. Mineral. Petrol. 1999, 134, 325-341.

104. Perez, W.A.; Kawashita, K. K-Ar and Rb-Sr geochronology of igneous rocks from the Sierra de Paiman, northwestern Argentina. J. S. Am. Earth Sci. 1992, 5, 251-264.

105. Lucassen, F.; Becchio, R.; Harmon, R.; Kasemann, S.; Franz, G.; Trumbull, R.; Wilke, H.G.; Romer, R.L.; Dulski, P. Composition and density model of the continental crust at an active continental margin - The Central Andes between $21^{\circ}$ and $27^{\circ} \mathrm{S}$. Tectonophysics 2001, 341, 195-223.

106. Lucassen, F.; Franz, G.; Thirlwall, M.F.; Mezger, K. Crustal recycling of metamorphic basement: Late Palaeozoic granitoids of northern Chile (similar to $22^{\circ} \mathrm{S}$ ). Implications for the composition of the Andean crust. J. Petrol. 1999, 40, 1527-1551. 
107. Lucassen, F.; Harmon, R.; Franz, G.; Romer, R.L.; Becchio, R.; Siebel, W. Lead evolution of the pre-Mesozoic crust in the Central Andes $\left(18-27^{\circ} \mathrm{S}\right)$ : Progressive homogenisation of $\mathrm{Pb}$. Chem. Geol. 2002, 186, 183-197.

108. Lucassen, F.; Escayola, M.; Romer, R.L.; Viramonte, J.; Koch, K.; Franz, G. Isotopic composition of late Mesozoic basic and ultrabasic rocks from the Andes (23-32 $\left.{ }^{\circ} \mathrm{S}\right)$-Implications for the Andean mantle. Contrib. Mineral. Petrol. 2002, 143, 336-349.

109. Lucassen, F.; Franz, G.; Romer, R.L.; Schultz, F.; Dulski, P.; Wemmer, K. Pre-Cenozoic intra-plate magmatism along the Central Andes (17-34 $\left.{ }^{\circ} \mathrm{S}\right)$ : Composition of the mantle at an active margin. Lithos 2007, 99, 312-338.

110. Lucassen, F.; Franz, G.; Viramonte, J.; Romer, R.L.; Dulski, P.; Lang, A. The Late Cretaceous lithospheric mantle beneath the Central Andes: Evidence from phase equilibria and composition of mantle xenoliths. Lithos 2005, 82, 379-406.

111. Huang, W.L.; Wyllie, P.J. Phase-relationships of gabbro-tonalite-granite-water at 15-kbar with applications to differentiation and anatexis. Am. Mineral. 1986, 71, 301-316.

112. Litvinovsky, B.A.; Steele, I.M.; Wickham, S.M. Silicic magma formation in overthickened crust: Melting of charnockite and leucogranite at 15, 20 and 25 kbar. J. Petrol. 2000, 41, 717-737.

113. Ort, M.H.; Coira, B.L.; Mazzoni, M.M. Generation of a crust-mantle magma mixture: Magma sources and contamination at Cerro Panizos, Central Andes. Contrib. Mineral. Petrol. 1996, 123, 308-322.

114. Soler, M.M.; Caffe, P.J.; Coira, B.L.; Onoe, A.T.; Kay, S.M. Geology of the Vilama caldera: A new interpretation of a large-scale explosive event in the Central Andean plateau during the Upper Miocene. J. Volcanol. Geotherm. Res. 2007, 164, 27-53.

115. Morgan, G.B.; London, D.; Luedke, R.G. Petrochemistry of Late Miocene peraluminous silicic volcanic rocks from the Morococala field, Bolivia. J. Petrol. 1998, 39, 601-632.

116. Davidson, J.; Turner, S.; Handley, H.; Macpherson, C.; Dosseto, A. Amphibole "sponge" in arc crust? Geology 2007, 35, 787-790.

117. Davidson, J.; Turner, S.; Plank, T. Dy/Dy*: variations arising from mantle sources and petrogenetic processes. J. Petrol. 2013, 54, 525-537.

118. Defant, M.J.; Drummond, M.S. Derivation of some modern arc magmas by melting of young subducted lithosphere. Nature 1990, 347, 662-665.

119. Melzer, S.; Wunder, B. Island-arc basalt alkali ratios: Constraints from phengite-fluid partitioning experiments. Geology 2000, 28, 583-586.

120. Kushiro, I.; Nakamura, Y.; Haramura, H.; Akimoto, S.I. Crystallization of some lunar mafic magmas and generation of rhyolitic liquid. Science 1970, 167, 610-612.

121. Kushiro, I.; Syono, Y.; Akimoto, S.I. Melting of a peridotite nodule at high pressures and high water pressures. J. Geophys. Res. 1968, 73, 6023-6029.

122. Kushiro, I.; Yoder, H.S.; Nishikaw, M. Effect of water on melting of enstatite. Geol. Soc. Am. Bull. 1968, 79, 1685-1692.

123. Tatsumi, Y.; Hamilton, D.L.; Nesbitt, R.W. Chemical characteristics of fluid phase released from a subducted lithosphere and origin of arc magmas: Evidence from high-pressure experiments and natural rocks. J. Volcanol. Geotherm. Res. 1986, 29, 293-309. 
124. Mcculloch, M.T.; Gamble, J.A. Geochemical and geodynamical constraints on subduction zone magmatism. Earth Planet. Sci. Lett. 1991, 102, 358-374.

125. Heydolph, K.; Hoernle, K.; Hauff, F.; van den Bogaard, P.; Portnyagin, M.; Bindeman, I.; Garbe-Schonberg, D. Along and across arc geochemical variations in NW Central America: Evidence for involvement of lithospheric pyroxenite. Geochim. Cosmochim. Acta 2012, 84, 459-491.

126. Hofmann, A.W. Chemical Differentiation of the Earth: The relationship between mantle, continental crust, and oceanic crust. Earth Planet. Sci. Lett. 1988, 90, 297-314.

127. Harmon, R.S.; Barreiro, B.A.; Moorbath, S.; Hoefs, J.; Francis, P.W.; Thorpe, R.S.; Deruelle, B.; Mchugh, J.; Viglino, J.A. Regional O-isotope, Sr-isotope, and Pb-isotope relationships in Late Cenozoic calc-alkaline lavas of the Andean Cordillera. J. Geol. Soc. Lond. 1984, 141, 803-822.

128. Davidson, J.P.; de Silva, S.L. Volcanic-rocks from the Bolivian Altiplano: insights into crustal structure, contamination, and magma genesis: Comment and reply. Geology 1992, 21, 1147-1149.

(C) 2013 by the authors; licensee MDPI, Basel, Switzerland. This article is an open access article distributed under the terms and conditions of the Creative Commons Attribution license (http://creativecommons.org/licenses/by/3.0/). 